\title{
Trophic relationships between metazooplankton communities and their plankton food sources in the Iles Eparses (Western Indian Ocean)
}

\author{
Christine Dupuy ${ }^{\mathrm{a},{ }^{*}, 1}$, Marc Pagano ${ }^{\mathrm{b}, 1}$, Patrice Got ${ }^{\mathrm{c}}$, Isabelle Domaizon ${ }^{\mathrm{d}}$, \\ Alexis Chappuis a , Guillaume Marchessaux ${ }^{\mathrm{b}}$, Marc Bouvy ${ }^{\mathrm{c}, 1}$ \\ a Littoral, Environnement et Sociétés (LIENSS) UMR 7266 CNRS, Université de La Rochelle, 2 rue Olympe de Gouges, 17000, La Rochelle, France \\ ${ }^{\mathrm{b}}$ Mediterranean Institute of Oceanography, Aix Marseille Université, CNRS, Université de Toulon, IRD, MIO UM 110, 13288, Marseille, France \\ ${ }^{\mathrm{C}}$ MARBEC, UMR 248, IRD, Ifremer, Université Montpellier, CNRS, Université Montpellier, Place E. Bataillon, Case 093, 34095, Montpellier Cedex 5, France \\ ${ }^{\mathrm{d}}$ CARRTEL, UMR 42, INRA, 75 avenue de Corzent, 74203, Thonon-les-bains, France
}

\section{A R T I C L E I N F O}

\section{Article history:}

Received 18 November 2015

Received in revised form

21 February 2016

Accepted 23 February 2016

Available online 27 February 2016

\section{Keywords:}

Metazooplankton

Spatial distribution

Grazing effect

Feeding ecology

Iles Eparses

Mayotte

\begin{abstract}
A B S T R A C T
Coral reef and atoll lagoons are among the most diversified marine ecosystems but also the most affected by the combined effects of climate change and human activities. The Iles Eparses (Scattered Islands) in the Western Indian Ocean have been little affected by human pressure and can be considered to be "pristine" ecosystems. Metazooplankton plays a major role in the functioning and productivity of aquatic ecosystems, and this study was undertaken: (i) to determine the spatial abundance, distribution and species composition of metazooplankton, (ii) to assess the effect of metazooplankton grazing on picoand nanophytoplankton and (iii) to analyze the trophic positions of metazooplankton by using the stable isotope signatures of a wide variety of taxa and particulate organic matter from the lles Eparses and Mayotte. Tromelin Island (which is not located in the Mozambique Channel) had the lowest metazooplankton abundance with no cyanobacteria Trichodesmium spp. or mollusks (pteropods) presence, and with $\delta^{15} \mathrm{~N}$ signatures of organisms that were higher than for the islands in the Mozambique Channel. Trichodesmium spp. was found in the Mozambique Channel and the plankton food web was probably based preferentially on these cyanobacteria with lower $\delta^{15} \mathrm{~N}$ signatures indicating direct or indirect trophic transfer of diazotrophic nitrogen to metazooplankton. Three of the islands were distinct: Europa had the highest proportion of copepods, with oithonids being dominant, which is typical of rich mangrove systems, while Juan de Nova and Mayotte seemed to be the sites most affected by human activity with a high abundance of appendicularians and distinct particulate organic matter ${ }^{13} \mathrm{C}$ signatures. Grazing experiments showed that food could be a limiting factor for metazooplankton in the Iles Eparses. However, the effect of metazooplankton grazing on phytoplankton appeared to be very low $(0.01-2.32 \%$ of the total phytoplankton per day).
\end{abstract}

() 2016 Elsevier Ltd. All rights reserved.

\section{Introduction}

Metazooplankton (defined as metazoan planktonic organisms) plays a major role in the functioning and productivity of aquatic ecosystems through its effect on nutrient dynamics and its key position in food webs (Harris et al., 2000). Most of these organisms exert a strong grazing effect on phytoplankton and protozooplankton (Pont, 1995; Calbet et al., 2008). They are also

\footnotetext{
* Corresponding author.

E-mail address: cdupuy@univ-lr.fr (C. Dupuy).

1 These are the joint main authors of this paper.
}

considered to be prey for small pelagic fishes, shrimps and mysids (Viitasalo and Rautio, 1998; Pollack et al., 2008; Spinelli et al., 2012). Several studies have suggested that climate-mediated changes in metazooplankton abundance and composition may affect upper trophic levels and fisheries (Beaugrand, 2003). Metazooplankton can also be used as biological indicators for pollution, water quality and eutrophication (Attayde and Bozelli, 1998; Webber et al., 2005).

For a long time, copepods (which constitute the bulk of metazooplankton in the oceans; Kiørboe, 1998) were thought to be strictly herbivorous, consuming $10 \%-30 \%$ of primary production, particularly diatoms. Poulet (1983) suggested that copepods could potentially obtain food from any known stock of organic matter, in either dissolved or particulate form. The food web is, therefore, 
more complex than just diatoms to copepods to pelagic fishes, with the microbial food web having intermediate trophic levels (microzooplankton, nanoplankton) (Rassoulzadegan et al., 1988). A large number of laboratory studies have been undertaken into the ingestion and egg production rates of copepods feeding mainly on monospecific or mixed phytoplankton diets (Paffenhöfer et al., 1982; Kiørboe et al., 1985; Caparroy et al., 1998). Since the establishment of the trophic link between the microbial community and copepods (Stoecker and Sanders, 1985; Gifford and Dagg, 1988), many studies have confirmed copepod predation on microzooplankton (e.g. Stoecker and Egloff, 1987; Vargas and Gonzáles, 2004). In particular, the importance of ciliates as food for copepods is now well understood (Stoecker and Egloff, 1987; Tiselius, 1989). Copepods are able to discriminate between different foods on the basis of particle size and food quality (Irigoien et al., 2000).

The diet of metazooplankton has been studied in the laboratory using grazing experiments (Mauchline, 1998), in cinematographic studies (Paffenhöfer et al., 1982) and, in the field, through microscopic examination of fecal pellets (Turner, 1984). Food web studies have also been based on carbon and nitrogen isotopic ratios. For carbon, there appears to be, on average, a slight enrichment of ${ }^{13} \mathrm{C}$ in a consumer relative to its diet $(0.5 \% 0-1 \%)$, and, for nitrogen, a more significant enrichment of ${ }^{15} \mathrm{~N}(3 \% 0-4 \%$; Michener and Kaufman, 2007). The lower isotopic fractionation for carbon can be useful in tracing two food sources with distinctly different $\partial^{13} \mathrm{C}$ values, whereas nitrogen isotope ratios are usually used as trophic position indicators (Peterson and Fry, 1987). Stable isotope analysis is a powerful, complementary approach to traditional feeding studies and has proved invaluable for understanding the food web structure and energy flow in aquatic ecosystems.

Coral reef and atoll lagoons are among the most diversified marine ecosystems although they are the most affected by the combined effects of climate change and human activities. The Iles Eparses (Scattered Islands) located in the Western Indian Ocean (WIO) around Madagascar have been little affected by human action and can be considered to be "pristine" ecosystems (Bouvy et al., 2016). In these islands, which form the 5th district of the French Southern and Antarctic Lands (TAAF), the coral reef lagoons may, therefore, be considered as baseline sites for the general evaluation of the impact of anthropogenic forcing. In coral reef and atoll lagoon environments, metazooplankton are part of the benthic and pelagic food webs and play a fundamental role in sustaining biodiversity and productivity in these fragile ecosystems (Bozec et al., 2004; Alldredge and King, 2009). However, few studies have considered the metazooplankton community structure and trophic relationships in atoll lagoons (Gerber, 1981; Pagano et al., 2012) and there is no data on the lagoons of the Iles Eparses.

As part of the international program "Eparses 2011-2013", a survey was carried out in April 2011 on board the R/V Marion Dufresne II, the TAAF supply vessel, to collect data from lagoon and ocean stations in each of the five Iles Eparses, with an additional station in Mayotte lagoon. This was the first time that microbial communities and their interactions with their environmental conditions had been studied at different types of site (lagoon and ocean) for each of the five Iles Eparses (Bouvy et al., 2016).

This study sets out (i) to determine the spatial abundance, distribution and species composition of metazooplankton, (ii) to assess the effect of metazooplankton grazing on pico- and nanophytoplankton through a series of experiments, and (iii) to analyze the trophic positions of metazooplankton by using the stable isotope signatures of a wide variety of taxa and particulate organic matter from the Iles Eparses and Mayotte.

\section{Material and methods}

\subsection{Study site and sampling strategy}

The Iles Eparses (Scattered Islands) are small coral reef islands located in the Indian Ocean close to Madagascar (from $22^{\circ} 21^{\prime} \mathrm{S}$ to $12^{\circ} 46^{\prime} \mathrm{S}$ and $39^{\circ} 44^{\prime} \mathrm{E}$ to $54^{\circ} 31^{\prime} \mathrm{E}$, Fig. 1 ), and became the 5 th district of the French Southern and Antarctic Lands (TAAF) in February 2007. Four of these islands lie in the Mozambique Channel, west of Madagascar (from south to north: Europa, Bassas da India, Juan de Nova and Glorieuses) and the fifth (Tromelin island) lies about $450 \mathrm{~km}$ east of Madagascar (Fig. 1). Lagoon areas are very variable according to the island, with 193, 165, 87 and $47 \mathrm{~km}^{2}$ for Juan de Nova, Glorieuses, Bassas da India and Europa, respectively. Due to its geographical location, Mayotte lagoon, which suffers from anthropogenic impacts as the result of a population explosion (Gourbesville and Thomassin, 2000), has also been sampled during the survey. Geographical coordinates of each station were reported in Bouvy et al. (2016).

The survey was based on 16 stations (Table 1) with water and plankton samples taken from April 5 to April 23, 2011 for each island (Fig. 1). One ocean station outside the lagoon and a number of lagoon stations depending on the area of the lagoon were sampled by island except in Tromelin Island (without lagoon) (Table 1). To determine the chemical and microbial parameters, water was sampled at depths of $0.5 \mathrm{~m}$ and $10 \mathrm{~m}$ (when it is possible; Table 1) using a Niskin bottle. The samples from the two depths were pooled, transferred immediately to acid-washed polyethylene bottles and kept in the dark at in situ temperatures until processed in the laboratory on board within $2 \mathrm{~h}$. At each sampling station, a CTD profiler (YSI $600 \mathrm{XM}$ ) was deployed to record the temperature, salinity, depth, dissolved oxygen and $\mathrm{pH}$ along a vertical profile. These results are presented elsewhere (Bouvy et al., 2016).

Metazooplankton was collected in 2 vertical hauls (bottom to surface) using a $80 \mu \mathrm{m}$ mesh WP2 net equipped with a Hydrodata flowmeter. At each station, one haul was used for stable isotope analysis and grazing experiments and the second haul was fixed with formaldehyde at $4 \%$ final concentration and used for identification and enumeration of the taxa. At the lagoon station of Bassas da India (station $\mathrm{BL}$ ), where samples were taken directly on the reef barrier at ebb tide (water depth ca $0.5-1 \mathrm{~m})$, a smaller net $(0.3 \mathrm{~m}$ diameter, $80 \mu \mathrm{m}$ mesh size) was used, "towed" horizontally at mid depth, using the current.

For grazing experiments of metazooplankton, wild metazooplankton was collected by vertical haul using a $200 \mu \mathrm{m}$ mesh WP2 net (see paragraph 2.4).

\subsection{Autotrophic components}

Pico- and nanophytoplankton samples were fixed with formaldehyde ( $2 \%$ final concentration), and counted using a Facs Aria Flow cytometer (Becton Dickinson, San Jose, CA, USA) equipped with an HeNe air-cooled laser (633 nm, $20 \mathrm{~mW}$ ). Cells excited at $633 \mathrm{~nm}$ were detected and enumerated according to their forward-angle light scatter (FALS) and right angle light scatter (RALS) properties and their orange fluorescence $(576 / 26 \mathrm{~nm}$ ) and red fluorescence (>650 nm) from phycoerythrin and chlorophyll pigments, respectively. Fluorescent beads (1-2 $\mu \mathrm{m}$ for picophytoplankton and 2-6-10-20 $\mu \mathrm{m}$ for nanophytoplankton) were systematically added to each sample. List-mode files were analyzed using BD FACSDiva software. This method discriminates various autotrophic groups such as autotrophic picoeukaryotes, picocyanobacteria (for example, Prochlorococcus and Synechococcus) and nanophytoplankton using their phycoerythrin content and chlorophyll pigments (Bouvy et al., 2016). 


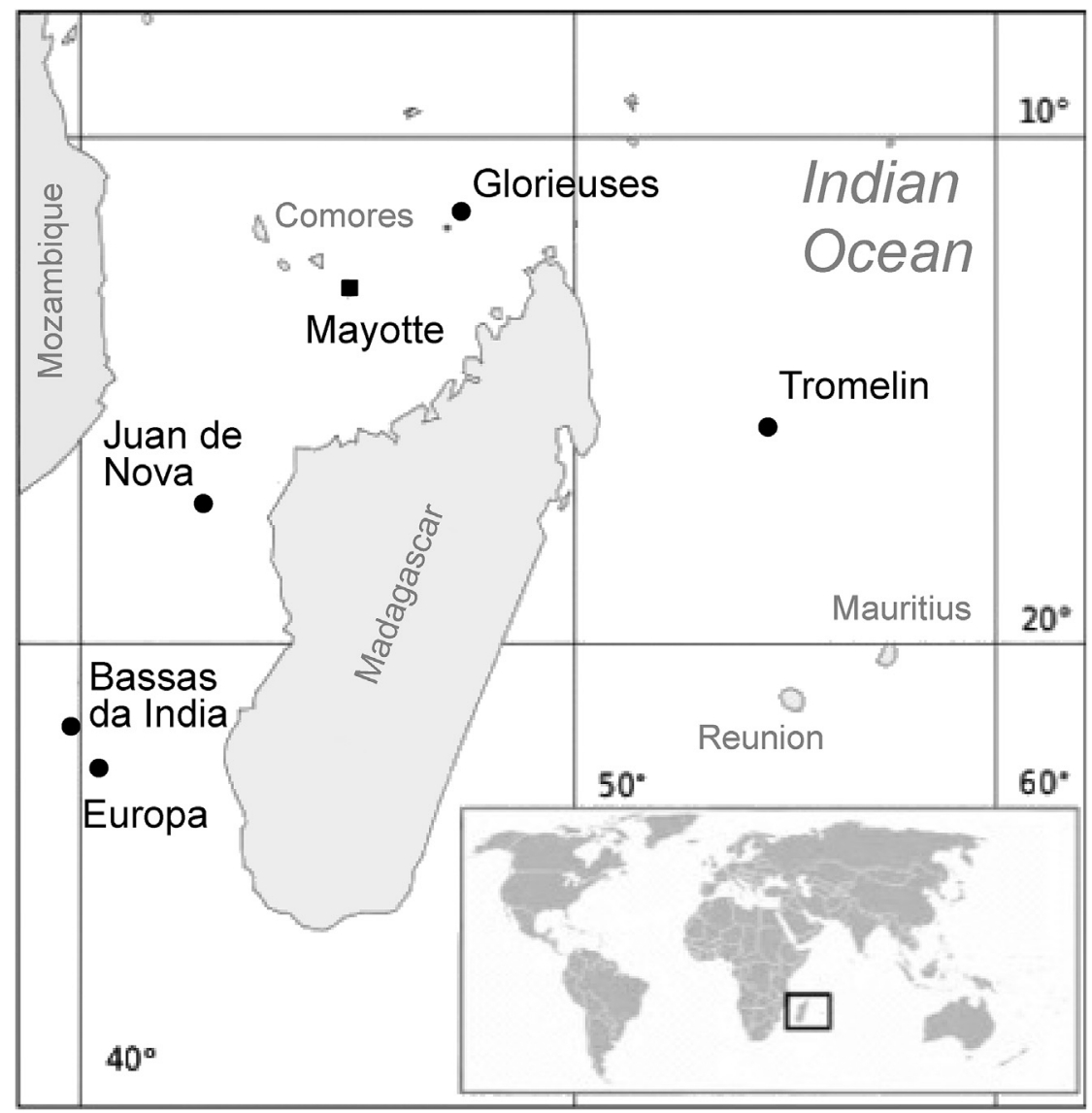

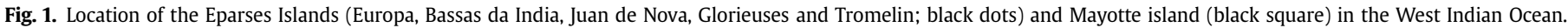

Table 1

List of stations studied in the five Iles Eparses and in Mayotte Island in West Indian Ocean in April 2011. Site code for each station and mean of some biological parameters of the 16 studied sites (lagoon and oceanic stations) are reported from the $0.5 \mathrm{~m}$ depth samplings. Maximum depth are reported for the lagoon stations. Picoeuk: picoeukaryotes; Picocya: picocyanobacteria; Nano: nanophytoplankton; Chloro: chlorophyll-a; nd: non determined.

\begin{tabular}{|c|c|c|c|c|c|c|}
\hline $\begin{array}{l}\text { Parameters } \\
\text { Units }\end{array}$ & Code & $\begin{array}{l}\text { Max depth } \\
\mathrm{m}\end{array}$ & $\begin{array}{l}\text { Picoeuk } \\
10^{3} \mathrm{ml}^{-1}\end{array}$ & $\begin{array}{l}\text { Picocya } \\
10^{3} \mathrm{ml}^{-1}\end{array}$ & $\begin{array}{l}\text { Nano } \\
10^{2} \mathrm{ml}^{-1}\end{array}$ & $\begin{array}{l}\text { Chloro } \\
\mu \mathrm{g} \mathrm{l}^{-1}\end{array}$ \\
\hline \multicolumn{7}{|l|}{ Europa } \\
\hline Ocean & EO & nd & 54.14 & 40.1 & 1.32 & 0.184 \\
\hline lagoon & E1 & 3 & 33.40 & 8.31 & 4.69 & 0.529 \\
\hline Lagoon & E2 & 4 & 57.59 & 4.95 & 4.48 & 0.522 \\
\hline Lagoon & E3 & 4 & 47.39 & 4.64 & 2.73 & 0.684 \\
\hline \multicolumn{7}{|c|}{ Bassas da India } \\
\hline Ocean & BO & nd & 47.11 & 34.6 & 1.06 & 0.340 \\
\hline Lagoon & $\mathrm{BL}$ & 1 & 32.86 & 39.3 & 2.01 & 0.581 \\
\hline \multicolumn{7}{|c|}{ Juan de Nova } \\
\hline Ocean & JO & nd & 0.30 & 18.1 & 1.50 & 0.164 \\
\hline Lagoon & $\mathrm{J} 1$ & 7 & 33.18 & 24.4 & 1.25 & 0.265 \\
\hline Lagoon & $\mathrm{J} 2$ & 14 & 93.23 & 78.5 & 2.95 & 0.555 \\
\hline Lagoon & J3 & 18 & 87.94 & 72.5 & 3.26 & 0.759 \\
\hline \multicolumn{7}{|l|}{ Mayotte } \\
\hline Lagoon & ML & 19 & 78.27 & 226.9 & 2.69 & 0.429 \\
\hline \multicolumn{7}{|l|}{ Glorieuses } \\
\hline Ocean & GO & nd & 2.76 & 20.5 & 1.35 & 0.162 \\
\hline Lagoon & G1 & 8 & 57.44 & 54.1 & 1.84 & 0.625 \\
\hline Lagoon & G2 & 10 & 146.50 & 112.0 & 3.68 & 0.526 \\
\hline Lagoon & G3 & 13 & 25.35 & 8.71 & 0.55 & 0.152 \\
\hline \multicolumn{7}{|l|}{ Tromelin } \\
\hline Ocean & TO & nd & 1.26 & 1.92 & 0.07 & 0.054 \\
\hline
\end{tabular}

Chlorophyll concentrations were determined by fluorometry after filtration onto Whatman GF/F fiberglass filters and direct extraction using methanol (Yentsch and Menzel, 1963).

The presence or absence of filamentous cyanobacteria (Trichodesmium spp.) was determined by observation (inverted microscope; Olympus IX70) of water samples (500 ml fixed with alcalin lugol iodine; $2 \%$ final concentration) with a Utermöhl settling chamber (Hydro-Bios combined plate chamber).

All these data are presented in detail in the companion paper (Bouvy et al., 2016). This study, however, focuses on the mean values per station to assess potential autotrophic components available as prey for metazooplankton.

\subsection{Metazooplankton identification}

The taxa were identified and enumerated using sub-samples taken using wide bore piston pipettes $(0.5-5 \mathrm{ml})$. At least 100 individuals of the main taxa were counted in each sub-sample under a dissecting microscope (Olympus SZX200, magnification $\times 200$ to $\times 500$ ). The rarest taxa were estimated from the whole sample. Metazooplankton taxa were identified as described by Tregouboff and Rose (1957), Razouls et al. (2005, 2014) and Conway et al. (2003).

\subsection{Grazing experiments of metazooplankton}

Eight grazing experiments were performed during the survey ( 5 ocean stations and 3 lagoon stations; EO, BO, JO, GO, TO and E2, J2, ML; see Table 1). We used the $>200 \mu \mathrm{m}$ metazooplankton fraction ( $>90 \%$ of the biomass) to minimize the introduction of nonzooplankton items in the experimental sets. After collection and 
sorting, homogeneous sets of total metazooplankton (25-50 individuals according to the sample abundance) were constituted volumetrically using a wide bore piston pipettes $5 \mathrm{ml}$ and quickly checked under a dissecting microscope. Then, organisms were incubated in $500 \mathrm{ml}$ flasks that had been filled with sea water sieved through $60 \mu \mathrm{m}$ net. For each experiment, three experimental bottles (with metazooplankton) and three controls (without metazooplankton) were prepared. The metazooplankton density in the bottles (50-100 ind $1^{-1}$ ) was up to 10 times greater than the in situ density, which is within the range of values currently used for metazooplankton grazing experiments (Harris et al., 2000). The bottles were incubated in the dark for about $24 \mathrm{~h}$ in a deck incubator with circulating surface seawater. At the end of the experiment, $1.8 \mathrm{ml}$ subsamples were taken from the bottles, fixed with prefiltered $(0.2 \mu \mathrm{m})$ formaldehyde ( $2 \%$ final concentration) and stored in liquid nitrogen for subsequent analysis of autotrophic groups (picoeukaryotes, picocyanobacteria with the genus Prochlorococcus and Synechococcus and nanophytoplankton) as described above. Largest potential prey (as diatoms or large dinoflagellates) were not considered due to their very low concentrations in the field (Bouvy et al., 2016), leading to a possible underestimation of total ingestion rates. The following factors were used to convert the abundance into carbon biomass: cyanobacteria: 119 fgCcell $^{-1}$ (mean value for Prochlorococcus and Synechococcus; Charpy and Blanchot, 1998); picoeukaryotes: 836 fgCcell $^{-1}$ (Verity et al., 1992); nanophytoplankton: 3140 fgCcell $^{-1}$ (Pelegri et al., 1999). The biovolumes of the cells were calculated by comparison with calibrated micro-beads.

At the end of the experiment, the metazooplankton from the bottles was transferred to a formalin solution (4\% final concentration) for subsequent enumeration and measurements in order to calculate the metazooplankton abundance and biomass. The individual weight of each taxon was estimated from their size measured under a dissecting microscope $(\times 500$ magnification $)$. The carbon weights of the organisms were then estimated using length-weight relationships given in the literature (Nassogne, 1972; Purcell, 1981; Uye, 1982; Chisholm and Roff, 1990; Mauchline, 1998).

The ingestion rates for each phytoplankton category and for total phytoplankton (I, expressed as $\mu \mathrm{m}^{3}$ ind $^{-1} \mathrm{~d}^{-1}$ or as $\mu \mathrm{gC} \mu \mathrm{gC}^{-1} \mathrm{~d}^{-1}$ ) were calculated from the difference in the cell concentration between the control (without zooplankton) and experimental bottles at the end of the experiment, assuming zero or negligible algal growth in the jar as the bottles had been kept in the dark (Pagano, 2008):

$I=C \mathrm{c}-\mathrm{Ce} /(V \times Z \times t)$;

where $C c$ and $C e$ are the cell concentrations (cell ml${ }^{-1}$ ) in the control and experimental bottles respectively, at the end of the incubation period, $V$ is the bottle volume $(\mathrm{ml}), Z$ is the metazooplankton abundance (or carbon biomass) per bottle and $t$ is the incubation time (day).

Selectivity coefficients $\left(\mathrm{W}_{i}\right)$ were calculated for each type of prey as described by Vanderploeg and Scavia (1979):

$\mathrm{W}_{\mathrm{i}}=\left(\mathrm{r}_{\mathrm{i}} / \mathrm{p}_{\mathrm{i}}\right) /\left(\mathrm{r}_{\mathrm{i}} / \mathrm{p}_{\mathrm{i}}\right) \max$

where $r_{i}$ is the percentage of the prey $i$ in the food ingested, $p_{i}$ is the percentage of the same prey in the available food and(ri/pi)max is the maximal $\left(\mathrm{r}_{\mathrm{i}} / \mathrm{p}_{\mathrm{i}}\right)$ value $\left(0<\mathrm{W}_{\mathrm{i}}<1\right)$.

The daily metazooplankton community grazing rate (cell $\mathrm{ml}^{-1} \mathrm{~d}^{-1}$ ) was estimated by multiplying the ingestion rates by the in situ metazooplankton abundance. It was expressed as a percentage of the in situ phytoplankton concentration consumed daily by the metazooplankton $\left(\% \mathrm{~d}^{-1}\right)$.

\subsection{Signature of stable isotopes of major plankton components}

At each station, samples were taken at depths of $0.5 \mathrm{~m}$ and $10 \mathrm{~m}$ using a Niskin bottle, and the water from the two depths at each station was pooled; for lagoons with several sampling stations, the samples from all the stations were also pooled (e.g. for Europa, EL in Fig. 6 represents the pooled samples from E1, E2 and E3 stations). Seawater subsamples ( $500 \mathrm{ml}-7 \mathrm{~L}$ depending on the station) were filtered onto a Whatman GF/F (47 mm in diameter). Filters were precombusted at $490{ }^{\circ} \mathrm{C}$ for $2 \mathrm{~h}$ to eliminate any organic carbon content. Each filter was oven-dried at $50^{\circ} \mathrm{C}$ and kept dry in sealed plastic bags until it was returned to La Rochelle University. For each station, four discs (10 $\mathrm{mm}$ in diameter) were cut from each filter and packed into individual tin capsules for stable isotope analysis of particulate organic matter (POM). As suggested by Kennedy et al. (2002), POM samples were decarbonated using $\mathrm{HCl}$ fumes to get rid of carbonates (as aragonite, dolomite and calcite) in order to obtain $\delta^{13} \mathrm{C}$ values of particulate organic carbon (POC). As the decarbonatation process alters $\delta^{15} \mathrm{~N}$ values we used $\delta^{15} \mathrm{~N}$ values from non-decarbonated subsamples of POM (Jacob et al., 2005).

For each station, the most abundant species, genera or taxa in the live samples were sorted on board. 20 to 300 individuals (depending on the size of the taxon) belonging to each taxon were fixed in $70 \%$ ethanol and sent to La Rochelle University for analysis. The samples were removed from the ethanol and washed carefully with distilled water to remove all the ethanol and/or dead organic matter and phytoplankton. When the organisms had been sorted and washed they were frozen $\left(-80^{\circ} \mathrm{C}, 48 \mathrm{~h}\right)$, freeze-dried $(24 \mathrm{~h})$ and then ground to a fine powder. A pool of individuals of each taxon was then packed into tin capsules for stable isotope analysis. The samples were not treated with acid to remove carbonates because previous studies did not find any significant changes in the relative abundance of ${ }^{13} \mathrm{C}$ and ${ }^{15} \mathrm{~N}$ before or after treatment with acid (Bode et al., 2004; Chouvelon et al., 2014).

The natural abundance of carbon and nitrogen stable isotopes in the plankton was determined using a Thermo Scientific Delta V Advantage mass spectrometer coupled to a Thermo Scientific Flash EA1112 elemental analyzer. The results were expressed as isotope ratios $\delta \mathrm{X}(\%)$ relative to international standards (Pee Dee Belemnite for carbon and atmospheric $\mathrm{N}_{2}$ for nitrogen), using the formula:

$\delta \mathrm{X}=\left[\left(\mathrm{R}_{\text {sample }} / \mathrm{R}_{\text {standard }}\right)-1\right] * 10^{3}$

where $\mathrm{X}$ is ${ }^{13} \mathrm{C}$ or ${ }^{15} \mathrm{~N}$ and $\mathrm{R}$ is ${ }^{13} \mathrm{C} /{ }^{12} \mathrm{C}$ or ${ }^{15} \mathrm{~N} /{ }^{14} \mathrm{~N}$ (Peterson and Fry, 1987).

Replicate measurements of internal laboratory standards (acetanilide) indicated a precision of approximately $0.2 \%$ for both $\delta^{13} \mathrm{C}$ and $\delta^{15} \mathrm{~N}$ values.

The carbon and nitrogen stable isotopes metazooplankton and Trichodesmium spp. data were corrected in relation with the mode of sample preservation (70\% ethanol) knowing their effect on the isotopic signatures (Chouvelon et al., 2014). This correction was applied according to Chouvelon et al. (2014):

- $\delta^{13} \mathrm{C}$ preservation corrected $=\left(\delta^{13} \mathrm{C} 70 \%\right.$ ethanol preserved, analyzed by mass spectrometry -8.18$) / 1.35$

- $\delta^{15} \mathrm{~N}$ preservation corrected $(\mathrm{B})=\left(\delta^{15} \mathrm{~N} 70 \%\right.$ ethanol preserved, analyzed by mass spectrometry -1.23$) / 0.92$.

The trophic positions (TPs) of each group (or genus or species) of metazooplankton were calculated according to Sommer and Sommer (2004) and Kürten et al. (2013). $\delta^{15} \mathrm{~N}$ of POM based TP 

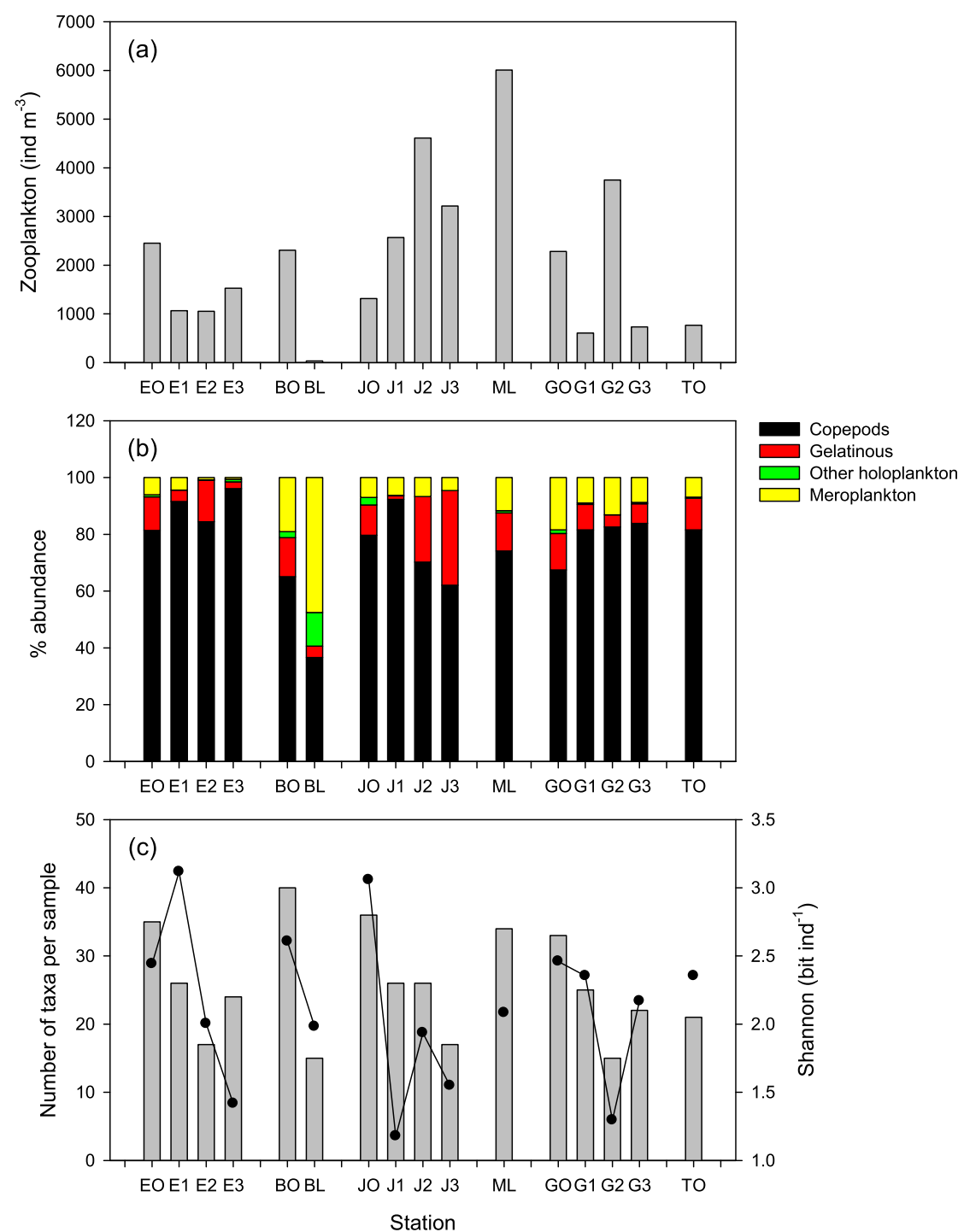

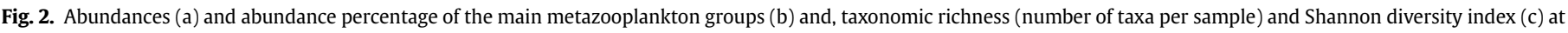
the different stations (see abbreviations in Table 1).

estimates assumed that TP POM values of 1 represented the isotopic baseline, and that a trophic fractionation factor of 3.4\% represented one trophic transfer (Minagawa and Wada, 1984):

$\mathrm{TP}=\left(\delta^{15} \mathrm{~N}\right.$ metazooplankton $\left.-\delta^{15} \mathrm{~N} \mathrm{POM}\right) / 3.4+1$

\subsection{Data analysis}

The spatial variation of the metazooplankton community composition was determined by Non-metric Multi-Dimensional Scaling (NMDS). A species/station matrix was created for abundance data. The abundance data were $\log \mathrm{x}+1$ transformed before estimating station similarity using the Bray Curtis metric. The similarity matrix was then ordinated by NMDS. A SIMPER (similarity percentage) analysis was performed to determine which species contributed most to the similarity or dissimilarity between stations for the groups of stations identified by NMDS. Nonparametric rank Kruskal-Wallis ANOVA was performed to compare the mean values of environmental and metazooplankton variables between the various clusters. Multiple linear regression was then used to determine which environmental variables were most strongly related to the community composition, with the first two dimensions of the NMDS analysis being the independent variables and the environmental variables being considered the dependent variables (Hosie and Cochran, 1994). The environmental variables used were longitude, latitude, depth, salinity, temperature (data in Bouvy et al., 2016), pico- and nanophytoplankton, chlorophyll- $a$, and carbon isotope signature $\left(\partial^{13} C\right)$ of the particulate organic matter (POM).

The spatial variation of the metazooplankton trophic positions was determined by hierarchical cluster analysis (HCA) using the Euclidean distance and complete linkage sorting.

\section{Results}

\subsection{Potential autotrophic prey for metazooplankton}

In a previous study, Bouvy et al. (2016) described the environmental conditions in terms of chemical and biological variables for all the ocean and lagoon stations sampled during the survey in 

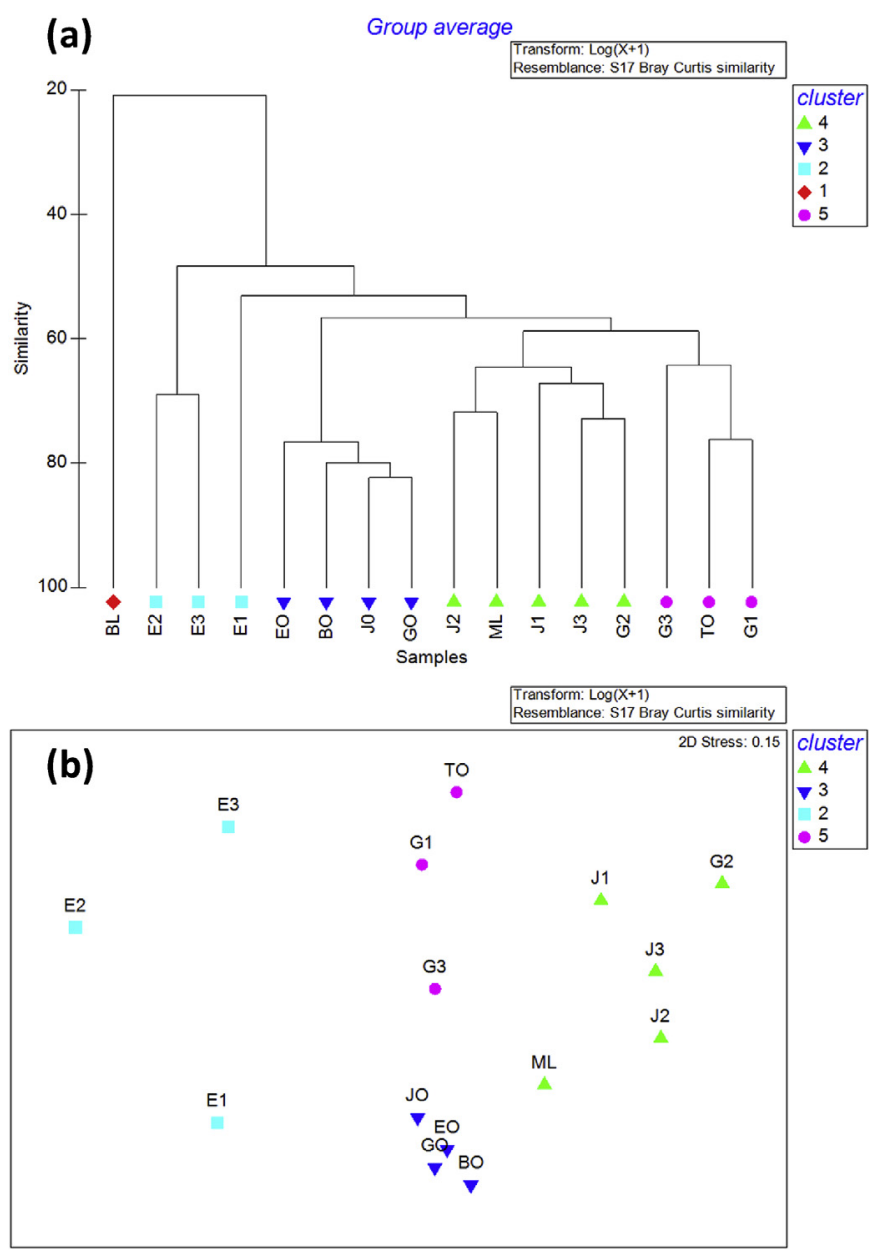

Fig. 3. Estimation of station similarity using the Bray Curtis metric based on the metazooplankton taxa abundance (square root transformed data): clusters spatial distribution and ordination (a) and Non-metric Multi-Dimensional Scaling (NMDS) (b). Station BL was considered as an outlier in the NDMS ordination.

April 2011. The mean values of environmental and trophic variables are shown in Table 1. The phytoplankton groups with the highest abundance were the picoeukaryotes (picoeuk) and the picocyanobacteria (picocya) mainly Synechococcus and Prochlorococcus. Picoeukaryotes and picocyanobacteria abundances were similar in the ocean and lagoon sites (mean of $21 \times 10^{3} \mathrm{ml}^{-1}$ and $23 \times 10^{3} \mathrm{ml}^{-1}$, respectively) whereas picoeukaryotes abundances were significantly higher in the lagoon sites, especially in the Europa lagoon (t-test; $\mathrm{p}<0.05$ ). There were very few nanophytoplankton cells (Nano) especially in the ocean sites (mean of $1.06 \times 10^{2} \mathrm{ml}^{-1}$ ). The mean chlorophyll- $a$ concentrations, considered here as a proxy of total phytoplankton biomass, were generally low and statistically different ( $\mathrm{t}$-test; $\mathrm{p}<0.05$ ) between the ocean and lagoon stations $\left(0.181 \mu \mathrm{g} \mathrm{l}^{-1}\right.$ in ocean and $0.507 \mu \mathrm{gl}^{-1}$ in lagoon sites).

\subsection{Metazooplankton abundance and species compositions}

Sixty taxa were enumerated during the survey (Table 2). They included 35 copepods (including undetermined nauplii and harpacticoids), 5 gelatinous taxa, 6 undetermined holoplanktonic groups and 11 meroplankton taxa. The number of taxa per sample varied from 15 to 40 , and the value was higher in the ocean station than in the adjacent lagoon stations for a given island.
Metazooplankton abundance varied from 33 to 6000 ind $\mathrm{m}^{-3}$, with the highest value for Mayotte (station ML) and the lowest for the reef barrier of Bassas da India (station BL) (Fig. 2a). Copepods were dominant, accounting for more than $70 \%$ of total metazooplankton abundance, except at station BL (37\%) where meroplankton was dominant (48\%) (Fig. 2b).

NDMS ordination of the metazooplankton taxa abundance data (stress value of 0.13 indicating a strong ordination) discriminated five clusters (Fig. 3): cluster 1 comprised only station BL, cluster 2 comprised the lagoon stations at Europa (stations E1, E2 and E3), cluster 3 comprised four ocean stations in the Mozambique channel (stations EO, BO, JO and GO), cluster 4 comprised lagoon stations, in particular those at Juan de Nova (stations J1, J2, J3, ML and G2) and cluster 5 comprised stations TO, G1 and G3. Overall, similarity between stations within a cluster was high $(>56 \%)$. Dissimilarity between clusters 2, 3, 4 and 5 ranged between 45 and 55\% while dissimilarity between cluster 1 and the other clusters was always greater than $71 \%$.

Cluster 1 was clearly distinct from the other four clusters. It was characterized by very low abundance of metazooplankton (33 ind $\mathrm{m}^{-3} v s>700$ ind $\mathrm{m}^{-3}$ in clusters $2,3,4,5$ ), by low taxa richness ( 15 taxa per sample $v s>22$ in clusters $2,3,4,5$ ) and by the dominance of meroplankton ( $48 \%$ of abundance $v s<14 \%$ in clusters $2,3,4,5)$. Copepod abundance in cluster 1 was only $37 \%$ ( $v s>75 \%$ in clusters 2, 3, 4, 5) (Figs. 2b, c, and 3).In clusters 2, 4 and 5, Oithona spp. was the taxa contributing the most to the similarity between stations within each cluster $(>12 \%)$ but the other major contributors depended on the cluster: Macrosetella spp. (11\%) and Oncaea spp. (11\%) for cluster 2, Appendicularian (10\%) and Trochophore larva (9\%) for cluster 4, (14\%), Corycaeus spp. (9\%) and Macrosetella spp. (9\%), for cluster 5 . In cluster 3, which included all the ocean stations located in the Mozambique Channel (EO, GO, JO and BO), Paracalanus spp. (6\%), Oithona spp. (6\%) and Corycaeus spp. (5.5\%) were the taxa contributing the most to the similarity between stations. Interestingly, this "ocean" cluster (cluster 3) had the highest mean values for taxonomic richness ( 36 taxa per sample $v s$ 15 for cluster 1 and between 22 and 24 for clusters 2, 4 and 5; no significant difference, Kruskal-Wallis ANOVA, p > 0.1). Furthermore, the mean Shannon diversity index $\left(2.65\right.$ bit ind $\left.^{-1}\right)$ for cluster 3 was significantly higher $(\mathrm{p}<0.001)$ than in the other clusters $\left(<2.20\right.$ bit ind $^{-1}$ ) (Fig. 2c).

Multiple regression analysis showed that the carbon isotope signature $\left(\partial^{13} \mathrm{C}\right)$ of the particulate organic matter $(\mathrm{POM})\left(\mathrm{r}^{2}=0.57\right.$, $\mathrm{p}=0.006)$, the biomass of nanophytoplankton $\left(\mathrm{r}^{2}=0.53\right.$, $\mathrm{p}=0.010)$, the biomass of picoeukaryotes $\left(\mathrm{r}^{2}=0.501, \mathrm{p}=0.015\right)$ and the temperature $\left(\mathrm{r}^{2}=0.49, \mathrm{p}=0.020\right)$ were the main variables strongly correlated with the taxa abundance distribution (represented by the first two dimensions of the NMDS) (data not shown).

\subsection{Metazooplankton grazing}

The metazooplankton taxonomic composition in the grazing flask was strongly dominated by copepods ( $>79 \%$ abundance) except at JL where gelatinous organisms (60\%) were dominant, and, to a lesser extent at GO, where meroplankton (19\%) was also very dominant (Table 2).

The prey composition varied from station to station (Fig. 4a) with picophytoplankton being the dominant fraction in terms of biovolume, except for the Europa lagoon stations $(E L=$ pooled $E 1$, E2 and E3) where nanophytoplankton was dominant. For station GO, picocyanobacteria dominated. In most cases, nanophytoplankton was the preferred prey for metazooplankton (stations $\mathrm{BO}, \mathrm{J} 2, \mathrm{JO}, \mathrm{TO}$ and $\mathrm{ML}$ ) while picocyanobacteria (Prochlorococcus and Synechococcus) were the preferred prey for 

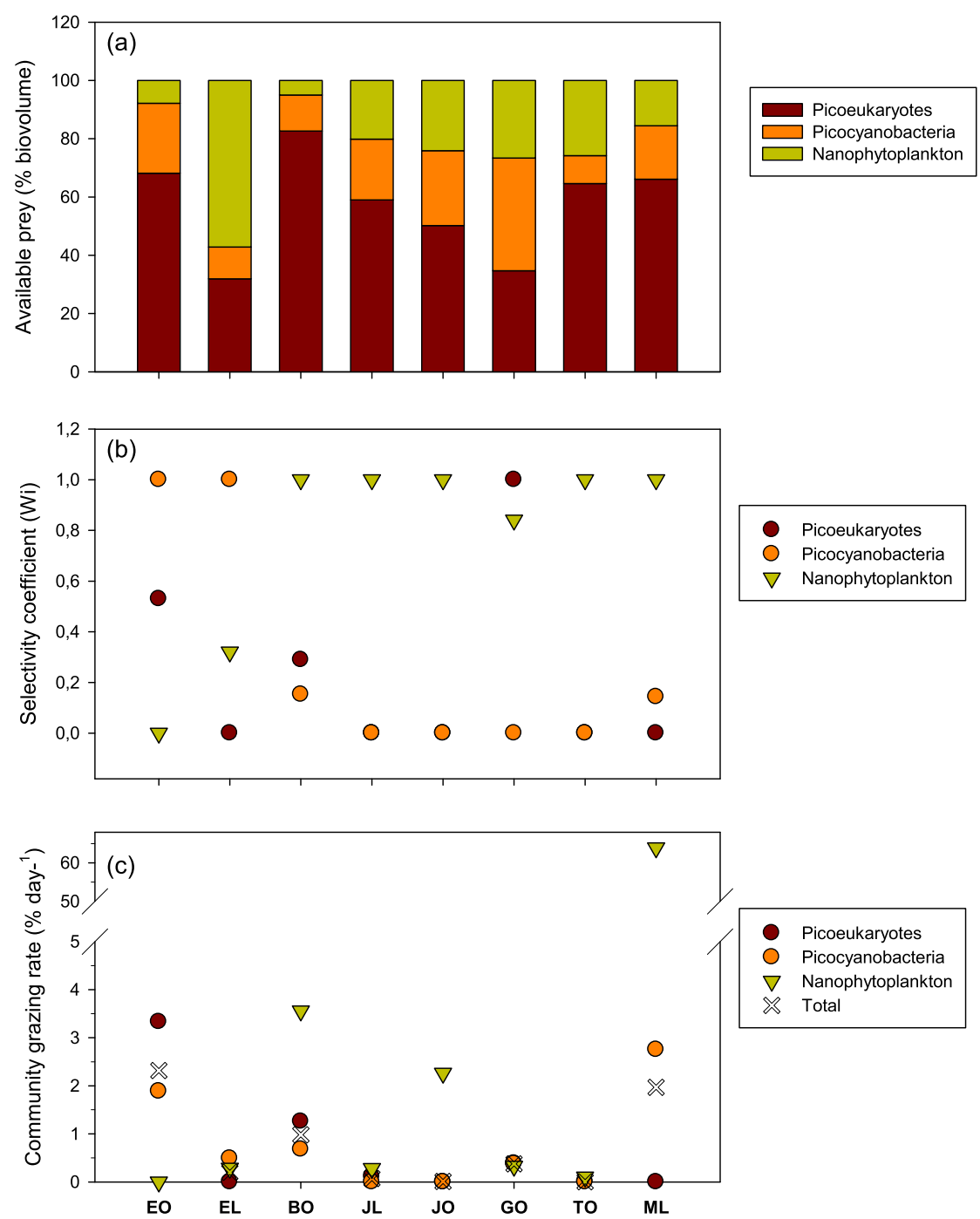

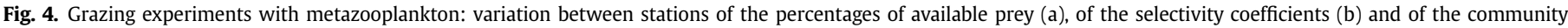

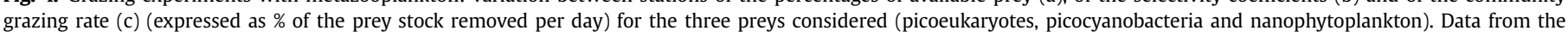
different lagoon stations at Europa and Juan de Nova (EL and JL) are averaged in order to have a mean value per lagoon (see M\&M section).

Europa (stations EO and EL) (Fig. 4b). For station GO, picoeukaryotes and nanophytoplankton were equally preferred while picocyanobacteria were not preferred despite their dominance in the water.

There was a significant positive correlation $(p<0.01)$ between total individual or weight-specific ingestion rates and food concentration (Fig. 5), showing that food could be a limiting factor for metazooplankton in the ecosystems. The highest ingestion rates were found for BO and EO and the lowest for TO, GO, JO and E2 with intermediate values for $\mathrm{J} 2$ and ML.

The daily community grazing rate varied from 0.2 to 1750 cells $\mathrm{ml}^{-1} \mathrm{~d}^{-1}$ and represented only a low fraction of the stocks of potential prey ( $<4 \%$ in most cases) (Fig. 4c) except for Mayotte lagoon where grazing had a significant effect on nanophytoplankton $\left(60 \% \mathrm{~d}^{-1}\right)$. This represented $0.01-2.32 \%$ of the total phytoplankton per day (Table 3 ).

\subsection{Stable isotope analysis of the major plankton components}

A wide variety of metazooplankton present in the stations was analyzed in order to cover a range of potential trophic positions (Table 4) and sources covered by the organisms (groups) that constitute the pelagic community (Fig. 6). As mentioned in the Material and methods section, the samples taken from various sampling stations in each lagoon for each island were pooled (EL, GL, JL). Typically, the lowest $\partial^{15} \mathrm{~N}$ were found for primary producers such as filamentous cyanobacteria Trichodesmium spp. $\left(\partial^{15} \mathrm{~N}=-0.988 \%\right.$ ) at all the stations in the Mozambique Channel. Copepods such as Oncaea spp., Macrosetella spp., Temora spp., Eucalanus spp., Calanus spp., Paracalanus spp., Oithona spp., Pontellidae, different larvae (undetermined fish, decapode, crab, shrimp, echinoderms) and salps and doliolids hava an average of $\partial^{15} \mathrm{~N}$ from 1.14 to $3.40 \%$. The highest values for $\partial^{15} \mathrm{~N}$ were recorded for chaetognaths (station TO; $\partial{ }^{15} \mathrm{~N}=10.18 \%$ ) followed by siphonophores $\left(\partial^{15} \mathrm{~N}=9.10 \%\right.$ ), Acartia sp. (station TO; $\partial{ }^{15} \mathrm{~N}=8.75 \%$ ), Eucheta sp. (station TO; $\partial{ }^{15} \mathrm{~N}=8.42 \%$ ), polychaete larvae $\left(\partial^{15} \mathrm{~N}=7.94 \%\right.$ ), salps and doliolids (station TO; $\partial^{15} \mathrm{~N}=7.81 \% \mathrm{o}$ ), Labidocera spp. $\left(\partial^{15} \mathrm{~N}=7.78 \%\right.$ ), Clausocalanus sp. and Oithona spp. (station TO; $\partial^{15} \mathrm{~N}=7.40 \%$ ) and the larvae of an undetermined fish (station E; $\partial^{15} \mathrm{~N}=7.18 \%$ ). Intermediate values of $\partial^{15} \mathrm{~N}$ (between 4 and $7 \% 0$ ) were found for the appendicularians, chaetognaths, megalope larva and copepods such as Acartia spp., Clausocalanus spp., Corycaeus spp., Eucheta spp., Oncea spp. (station GL), Temora spp. (station ML) and Undinula spp.. 

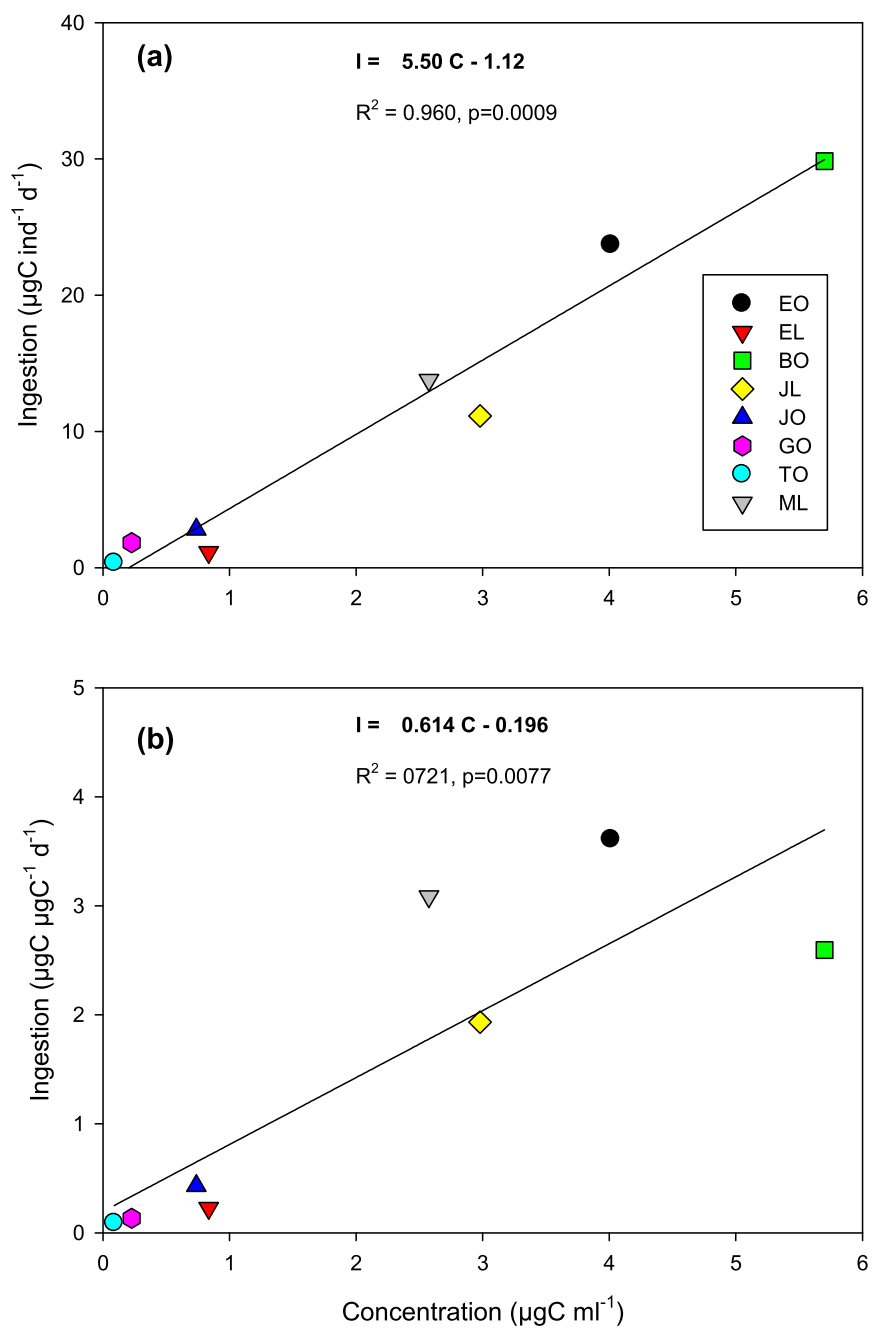

Fig. 5. Grazing experiments with metazooplankton: variations of the individual ingestion rate (a) and of the weight-specific (ie expressed per body carbon weigh) ingestion rate (b) with total food concentration expressed as carbon unit. Data from the different lagoon stations at Europa and Juan de Nova (EL and JL) are averaged in order to have a mean value per lagoon.

The trophic positions of metazooplankton taxa were calculated with $\delta^{15} \mathrm{~N}$ of metazooplankton and $\delta^{15} \mathrm{~N}$ POM (TP of POM $=1$ represented the isotopic baseline) assuming that a trophic fractionation factor of $3.4 \%$ represented one trophic transfer (Minagawa and Wada, 1984). Based on the TPs and HCA analysis, 4 groups of signatures could be distinguished (Fig. 7): (1) the group of Oithona spp. from the islands in the Mozambique Channel with the lowest TPs, (2) the group where TPs were low, from 0 to 0.43 , as Oncaea spp., Macrosetella spp., Eucalanus spp., Temora spp., Pontellidae and different types of meroplankton (larva), (3) the group where TPS were the highest, from 1.5 to 2.0, as Acartia spp. and Eucheta spp. from TO, Labidocera spp., chaetognaths from TO, siphonophora and fish larva from E, and finally, (4) the intermediary group where TPs were between 0.48 and 1.40 as appendicularia, chaetognaths and copepods such as Undinula spp. and Corycaeus spp..

The lowest average carbon isotope ratios for metazooplankton were found in Macrosetella spp. $\left(\partial^{13} \mathrm{C}=-21.51 \%\right.$ ) followed by doliolids $\left(\partial^{13} \mathrm{C}=-21.37 \%\right.$ ). The highest average carbon isotope ratios were found in shrimps from Juan de Nova lagoon (JL), Oithona spp. from Europa lagoon (EL) and decapod larvae from Glorieuses lagoon (GL) $\left(\partial^{13} \mathrm{C}=-15.39,-15.79\right.$ and $-17: 00 \%$; respectively).
POM isotope signatures were different from those of metazooplankton. The average POM $\partial{ }^{13} \mathrm{C}$ was $-23.96 \%$ with values ranging from -25.95 to $-20.39 \%$. POM $\partial^{13} \mathrm{C}$ signatures for JL and ML were closed to the signatures of ocean stations, and significantly different from the other lagoon systems of Bassas da India (BL), Glorieuses (GL) and Europa (EL). $\partial^{15} \mathrm{~N}$ ranged from 4.20 to $8.01 \%$ with an average of $5.32 \%$.

\section{Discussion}

The first regional study conducted in the Western Indian Ocean (WIO), provided a preliminary insight into the spatial distribution of the plankton communities in the Iles Eparses (Bouvy et al., 2016). Although these results should be interpreted with caution since they were obtained during only one season (April) and on the basis of one sample per station, the distribution patterns of microbial and metazooplankton components are apparently related to the location of the island in the WIO. The phytoplankton was dominated by picoeukaryotes and picocyanobacteria, as generally reported in oceanic waters (Flombaum et al., 2013). On average, these groups were significantly less abundant in ocean waters than in the lagoons. However, their concentrations were lower in the Europa mangroves as they are believed to be outcompeted by other phytoplankton in high-nutrient waters (Partensky et al., 1999). Europa Island was characterized by highly productive bacterial communities associated with mangroves (Bouvy et al., 2016). The marine ecosystem of Tromelin Island had the lowest biological productivity, with the lowest nutrient concentrations and bacterial growth rates, and a high ratio of heterotrophic bacteria to picoautotrophic organisms suggesting a microbial metabolism based on $\mathrm{CO}_{2}$ production. On the other hand, bacteria and nanoflagellate dynamics were closely linked at certain lagoon stations (J2, E2 and $\mathrm{BL}$ ) suggesting a potentially active microbial network. However, it has been demonstrated that both herbivorous and microbial grazing pathways of metazooplankton may play an important role in the transfer of matter and energy towards the top predators in these types of lagoon systems (Pagano et al., 2006, 2012). One of the aims of this study was to assess the effect of metazooplankton grazing on pico- and nanophytoplankton and to determine the trophic positions within the plankton ecosystem by analyzing the stable isotope signatures of a wide variety of taxa from all the islands sampled.

\subsection{Metazooplankton communities}

Multivariate analyses showed a strong divergence of metazooplankton taxa, reflecting differences in communities between the various sites. The metazooplankton community sampled from the coral reef of Bassas da India (station BL) was clearly characterized by very low abundance and diversity and by the dominance of meroplankton, mostly bivalve and gastropod larvae, which accounted for $>45 \%$ of the total abundance. These features are typical of coral reefs where the dominance of meroplankton is associated with the proximity of coral benthic communities and where the low metazooplankton abundance is partly due to consumption by planktivorous fishes when the water crosses the reef during ebb and flood tides (Hamner et al., 2007).

On the other hand, the ocean community in the Mozambique Channel (stations BO, EO, GO and JO) was characterized by the highest taxonomic richness and diversity and dominated by small copepods $(>70 \%)$, particularly Paracalanidae (12\%), followed by appendicularians (5\%) and chaetognaths (3\%). These characteristics are consistent with the community described by Huggett (2014) for the same area in the Mozambique Channel ( $14-25^{\circ} \mathrm{S}$ and $\left.36-43^{\circ} \mathrm{E}\right)$, including ocean stations close to Bassas da India and Juan de Nova. 


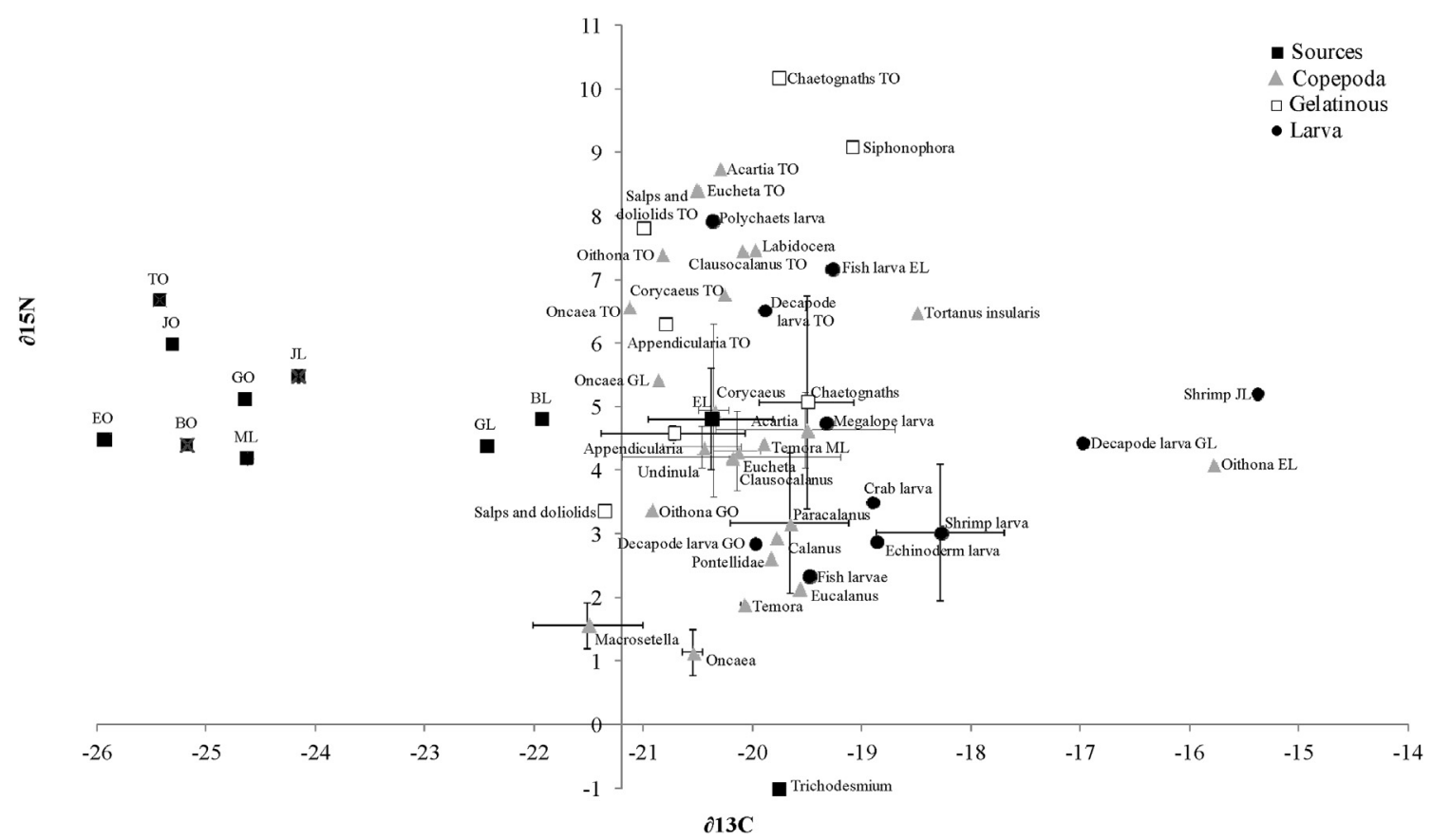

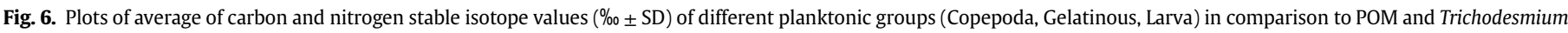

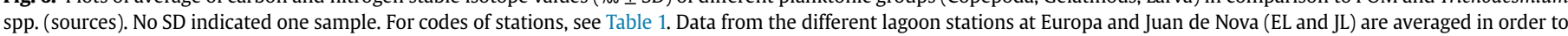
have a mean value per lagoon.

The metazooplankton community sampled at the ocean station of Tromelin Island (TO), to the east of Madagascar Island, had lower abundance and diversity than those observed in the Mozambique Channel, mainly due to a higher relative contribution of copepods (abundance $81 \%$ vs $73 \pm 4 \%$ ), especially Paracalanus spp. (20.5\% vs $11.6 \pm 2 \%$ ) and a lower contribution of meroplankton (6\%vs $13 \pm 3 \%$ ), mollusca (absent for TO) and amphipods.

The difference between the Tromelin Island and Mozambique Channel ocean communities may arise from the particular hydrodynamic features in the Mozambique Channel, which have been shown to have a strong effect on phytoplankton and zooplankton distribution clearly associated with ocean fronts and mesoscale eddies (Lamont et al., 2014; Huggett, 2014). The lower metazooplankton abundance for Tromelin Island is also consistent with previous results for microbial components (Bouvy et al., 2016) showing that Tromelin Island had the lowest biological productivity, with the lowest nutrient concentrations and bacterial growth rates. The absence of molluscs for Tromelin Island, in particular pteropods (such as Limacina spp. and Cavolinia spp.) is also consistent with this finding because these microphagous organisms were found to be highly dependent on the bacterial food chain (Gaudy et al., 1996).

The distribution of the lagoon metazooplankton communities could be classified into two groups of sites. The first group comprised the Europa lagoon stations (E1, E2 and E3), which were in a rich mangrove system. It was characterized by the highest mean proportion of copepods (91\%), and the dominance of oithonids (39\% of copepod abundance) which are typical of mangrove ecosystems (McKinnon and Klumpp, 1998; Ara, 2004). The second group comprised the Juan de Nova (J1, J2, J3) and Mayotte (ML) lagoon stations which can be considered as the sites most affected by human activities. Mayotte lagoon is affected by the urban and industrial activities of Mamoudzou harbor and Juan de Nova has been an important bird area with strong phosphate deposits that were exploited from the start of the 20th century until 1970 (Le Corre and Safford, 2001). In these sites, the metazooplankton had the highest mean abundance value $\left(4030 \pm 597\right.$ ind $\mathrm{m}^{-3}$, vs less than 1300 ind $\mathrm{m}^{-3}$ for the other lagoon sites), which may be due to higher primary production linked to fertilization by human activity (Mayotte) or bird guano (Juan de Nova). Furthermore, the POM $\partial^{13} \mathrm{C}$ signatures for JL and ML were significantly different from the other lagoon systems of Bassas da India (BL), Glorieuses (GL) and Europa (EL) and close to the signatures of ocean stations. The values of POM $\partial^{13} \mathrm{C}$ signatures at JL and ML can be affected by human activities cited above. In contrast, the lowest values of POM $\partial{ }^{13} \mathrm{C}$ signatures at ocean stations corresponded to a marine influence generally reported using natural stable isotope. Finally, Juan de Nova and Mayotte were also characterized by gelatinous plankton exclusively composed of appendicularians which are known to benefit from high phytoplankton productivity (Acuna et al., 2002; Lombard et al., 2009).

Relationships were found between several variables defining trophic conditions for metazooplankton (for example, biomass of nanophytoplankton and picoeukaryotes, POM $\partial^{13} \mathrm{C}$ ). These suggest a possible link between the structure of the metazooplankton communities and the origin and composition of the organic particulate matter of their biotopes (Fig. 6 and Table 4). This is consistent with the stable isotope analyses (see discussion below) showing clear differences in trophic structure between areas, in particular between Tromelin Island and the other islands in the Mozambique Channel.

\subsection{Trophic structure of metazooplankton}

The trophic positions calculated from $\delta^{15} \mathrm{~N}$ stable isotope analysis from POM and metazooplankton agreed globally with diet and trophic position found in the literature. Oncaea spp., Macrosetella spp., Temora spp., Eucalanus spp., Paracalanus spp., Calanus spp., Undinula spp., salps and doliolids (inside the Mozambique Channel), and different types of meroplankton (larva), showed a low trophic position $(<0.5)$ as reported by many studies (Madin and Kremer, 1995; Suzuki et al., 1999; Gibson and Paffenhöfer, 2000; 
Table 2

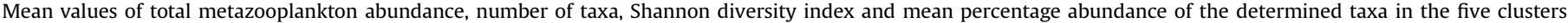
defined by the NDMS analysis. Copepod taxa are expressed as the sum of copepodites and adult stages.

\begin{tabular}{|c|c|c|c|c|c|}
\hline Taxa & Cluster 1 & Cluster 2 & Cluster 3 & Cluster 4 & Cluster 5 \\
\hline Total abundance (ind $\mathrm{m}^{-3}$ ) & 33.1 & $1215.3 \pm 157.0$ & $2084.5 \pm 261.1$ & $4031.3 \pm 596.7$ & $701.7 \pm 48.4$ \\
\hline Number of taxa & 15.0 & $22.3 \pm 2.7$ & $36.0 \pm 1.5$ & $23.6 \pm 3.4$ & $22.7 \pm 1.2$ \\
\hline Shannon index (bits ind ${ }^{-1}$ ) & 2.0 & $2.2 \pm 0.5$ & $2.6 \pm 0.1$ & $1.6 \pm 0.2$ & $2.3 \pm 0.1$ \\
\hline Copepoda \% & 36.6 & $96.0 \pm 3.4$ & $75.8 \pm 4.2$ & $75.5 \pm 5.2$ & $85.8 \pm 0.8$ \\
\hline Nauplii & 12.9 & $47.1 \pm 18.6$ & $23.2 \pm 6.6$ & $38.2 \pm 6.9$ & $33.8 \pm 2.1$ \\
\hline Paracalanus spp. & 3.0 & $6.0 \pm 2.9$ & $12.1 \pm 2.7$ & $7.2 \pm 3.9$ & $12.5 \pm 6.5$ \\
\hline Clausocalanus spp. & 0.0 & $0.9 \pm 0.9$ & $0.0 \pm 0.0$ & $0.1 \pm 0.1$ & $1.5 \pm 1.3$ \\
\hline Acartia spp. & 0.0 & $0.3 \pm 0.2$ & $1.7 \pm 0.8$ & $2.2 \pm 0.8$ & $1.4 \pm 0.3$ \\
\hline Centropages spp. & 0.0 & $0.1 \pm 0.1$ & $1.5 \pm 0.4$ & $0.5 \pm 0.4$ & $1.7 \pm 1.1$ \\
\hline Candacia varicans & 0.0 & $0.2 \pm 0.1$ & $0.2 \pm 0.0$ & $0.0 \pm 0.0$ & $0.1 \pm 0.1$ \\
\hline Temora spp. & 0.0 & $0.0 \pm 0.0$ & $0.3 \pm 0.1$ & $0.1 \pm 0.1$ & $0.0 \pm 0.0$ \\
\hline Mecynocera sp. & 0.0 & $0.2 \pm 0.2$ & $0.0 \pm 0.0$ & $0.0 \pm 0.0$ & $0.4 \pm 0.2$ \\
\hline Calanus spp. & 0.0 & $1.4 \pm 0.6$ & $0.3 \pm 0.0$ & $0.1 \pm 0.1$ & $0.3 \pm 0.3$ \\
\hline Acrocalanus sp. & 0.0 & $0.4 \pm 0.0$ & $0.0 \pm 0.0$ & $0.2 \pm 0.1$ & $0.0 \pm 0.0$ \\
\hline Nanocalanus sp. & 0.0 & $0.2 \pm 0.2$ & $0.3 \pm 0.3$ & $0.0 \pm 0.0$ & $0.1 \pm 0.1$ \\
\hline Calocalanus sp. & 0.0 & $0.0 \pm 0.0$ & $4.6 \pm 1.2$ & $0.1 \pm 0.0$ & $0.8 \pm 0.4$ \\
\hline Eucalanus sp. & 0.0 & $0.0 \pm 0.0$ & $0.3 \pm 0.1$ & $0.0 \pm 0.0$ & $0.0 \pm 0.0$ \\
\hline Euchaeta sp. & 0.0 & $0.0 \pm 0.0$ & $0.1 \pm 0.1$ & $0.0 \pm 0.0$ & $0.0 \pm 0.0$ \\
\hline Phaenna sp. & 0.0 & $0.0 \pm 0.0$ & $0.0 \pm 0.0$ & $0.1 \pm 0.1$ & $0.0 \pm 0.0$ \\
\hline Tortanus insularis & 0.0 & $0.0 \pm 0.0$ & $0.1 \pm 0.1$ & $1.5 \pm 0.3$ & $0.0 \pm 0.0$ \\
\hline Rhincalanus sp. & 0.0 & $0.1 \pm 0.1$ & $0.9 \pm 0.4$ & $0.0 \pm 0.0$ & $0.0 \pm 0.0$ \\
\hline Calanopia minor & 0.0 & $0.1 \pm 0.0$ & $0.2 \pm 0.0$ & $0.0 \pm 0.0$ & $0.0 \pm 0.0$ \\
\hline Pseudodiaptomus sp. & 0.0 & $0.0 \pm 0.0$ & $0.8 \pm 0.3$ & $0.0 \pm 0.0$ & $0.0 \pm 0.0$ \\
\hline Undinula vulgaris & 0.0 & $0.0 \pm 0.0$ & $0.2 \pm 0.1$ & $0.0 \pm 0.0$ & $0.0 \pm 0.0$ \\
\hline Lubockia sp. & 0.0 & $0.0 \pm 0.0$ & $0.0 \pm 0.0$ & $0.0 \pm 0.0$ & $0.0 \pm 0.0$ \\
\hline Unidentified calanoid & 0.0 & $0.0 \pm 0.0$ & $0.0 \pm 0.0$ & $0.0 \pm 0.0$ & $0.4 \pm 0.2$ \\
\hline Oncaea spp. & 0.0 & $6.9 \pm 3.0$ & $6.1 \pm 1.8$ & $0.6 \pm 0.4$ & $3.0 \pm 0.2$ \\
\hline Oithona spp. & 4.0 & $19.0 \pm 7.7$ & $12.8 \pm 3.5$ & $20.8 \pm 6.4$ & $17.6 \pm 3.6$ \\
\hline Corycaeus spp. & 1.0 & $0.7 \pm 0.6$ & $4.7 \pm 0.3$ & $0.6 \pm 0.4$ & $4.9 \pm 0.9$ \\
\hline Sapphirina sp. & 0.0 & $0.1 \pm 0.1$ & $0.0 \pm 0.0$ & $0.0 \pm 0.0$ & $0.0 \pm 0.0$ \\
\hline Copilia sp. & 0.0 & $0.1 \pm 0.1$ & $0.3 \pm 0.2$ & $0.0 \pm 0.0$ & $0.0 \pm 0.0$ \\
\hline Euterpina sp. & 6.9 & $5.0 \pm 4.7$ & $0.0 \pm 0.0$ & $0.2 \pm 0.2$ & $0.0 \pm 0.0$ \\
\hline Clytemnestra sp. & 0.0 & $0.1 \pm 0.1$ & $0.0 \pm 0.0$ & $0.0 \pm 0.0$ & $0.0 \pm 0.0$ \\
\hline Tisbe sp. & 0.0 & $0.6 \pm 0.5$ & $0.0 \pm 0.0$ & $1.6 \pm 1.2$ & $0.9 \pm 0.7$ \\
\hline Macrosetella sp. & 0.0 & $4.9 \pm 2.1$ & $4.1 \pm 0.3$ & $1.4 \pm 0.5$ & $6.3 \pm 2.6$ \\
\hline Harpacticoid unidentified sp1 & 0.0 & $1.4 \pm 1.3$ & $0.7 \pm 0.2$ & $0.0 \pm 0.0$ & $0.0 \pm 0.0$ \\
\hline Harpacticoid unidentified sp2 & 7.9 & $0.1 \pm 0.1$ & $0.0 \pm 0.0$ & $0.0 \pm 0.0$ & $0.0 \pm 0.0$ \\
\hline Harpacticoid unidentified sp3 & 1.0 & $0.0 \pm 0.0$ & $0.1 \pm 0.1$ & $0.0 \pm 0.0$ & $0.0 \pm 0.0$ \\
\hline Harpacticoid unidentified sp4 & 0.0 & $0.2 \pm 0.2$ & $0.0 \pm 0.0$ & $0.0 \pm 0.0$ & $0.0 \pm 0.0$ \\
\hline Other holoplankton \% & 15.8 & $0.5 \pm 0.3$ & $1.6 \pm 0.4$ & $0.3 \pm 0.2$ & $0.4 \pm 0.0$ \\
\hline Ostracoda & 5.0 & $0.1 \pm 0.0$ & $0.0 \pm 0.0$ & $0.0 \pm 0.0$ & $0.4 \pm 0.0$ \\
\hline Amphipoda & 1.0 & $0.2 \pm 0.1$ & $0.3 \pm 0.2$ & $0.0 \pm 0.0$ & $0.0 \pm 0.0$ \\
\hline Isopoda & 4.0 & $0.3 \pm 0.3$ & $0.0 \pm 0.0$ & $0.0 \pm 0.0$ & $0.0 \pm 0.0$ \\
\hline Worms & 2.0 & $0.0 \pm 0.0$ & $0.0 \pm 0.0$ & $0.0 \pm 0.0$ & $0.0 \pm 0.0$ \\
\hline Mollusca (Pteropoda) & 0.0 & $0.0 \pm 0.0$ & $1.4 \pm 0.4$ & $0.2 \pm 0.2$ & $0.0 \pm 0.0$ \\
\hline Water mites & 4.0 & $0.0 \pm 0.0$ & $0.0 \pm 0.0$ & $0.1 \pm 0.1$ & $0.0 \pm 0.0$ \\
\hline Gelatinous \% & 0.0 & $1.6 \pm 3.8$ & $8.8 \pm 0.7$ & $15.2 \pm 5.9$ & $5.3 \pm 1.2$ \\
\hline Salps and doliolids & 0.0 & $0.0 \pm 0.0$ & $0.1 \pm 0.1$ & $0.0 \pm 0.0$ & $0.0 \pm 0.0$ \\
\hline Chaetognaths & 0.0 & $1.4 \pm 0.8$ & $2.8 \pm 0.6$ & $0.4 \pm 0.2$ & $1.9 \pm 0.7$ \\
\hline Medusae & 0.0 & $0.2 \pm 0.2$ & $0.8 \pm 0.1$ & $0.3 \pm 0.1$ & $0.6 \pm 0.3$ \\
\hline Appendicularia & 0.0 & $0.0 \pm 0.0$ & $4.9 \pm 1.0$ & $14.5 \pm 5.4$ & $2.2 \pm 0.3$ \\
\hline Siphonophora & 0.0 & $0.0 \pm 0.0$ & $0.2 \pm 0.1$ & $0.0 \pm 0.0$ & $0.7 \pm 0.2$ \\
\hline Larva (meroplankton) \% & 47.5 & $1.9 \pm 1.2$ & $13.7 \pm 3.5$ & $9.0 \pm 1.7$ & $8.5 \pm 0.7$ \\
\hline Polychaetes & 5.9 & $0.4 \pm 0.1$ & $0.4 \pm 0.1$ & $0.5 \pm 0.2$ & $0.5 \pm 0.1$ \\
\hline Actinotroch & 0.0 & $0.1 \pm 0.1$ & $0.3 \pm 0.2$ & $0.5 \pm 0.2$ & $0.3 \pm 0.3$ \\
\hline Trochophores & 0.0 & $0.0 \pm 0.0$ & $4.3 \pm 1.6$ & $3.7 \pm 1.6$ & $1.7 \pm 1.7$ \\
\hline Gastropod & 9.9 & $0.2 \pm 0.2$ & $0.2 \pm 0.1$ & $3.3 \pm 2.5$ & $4.1 \pm 2.0$ \\
\hline Bivalve & 31.7 & $0.3 \pm 0.1$ & $0.5 \pm 0.2$ & $0.6 \pm 0.1$ & $0.7 \pm 0.3$ \\
\hline Decapod & 0.0 & $0.7 \pm 0.6$ & $6.7 \pm 3.7$ & $0.1 \pm 0.1$ & $0.5 \pm 0.3$ \\
\hline Euphausiid & 0.0 & $0.0 \pm 0.0$ & $0.1 \pm 0.0$ & $0.0 \pm 0.0$ & $0.1 \pm 0.1$ \\
\hline Cirriped & 0.0 & $0.0 \pm 0.0$ & $0.1 \pm 0.1$ & $0.0 \pm 0.0$ & $0.4 \pm 0.3$ \\
\hline Fish eggs & 0.0 & $0.2 \pm 0.1$ & $0.1 \pm 0.1$ & $0.2 \pm 0.2$ & $0.2 \pm 0.1$ \\
\hline Asteroid & 0.0 & $0.0 \pm 0.0$ & $0.5 \pm 0.1$ & $0.0 \pm 0.0$ & $0.0 \pm 0.0$ \\
\hline Undetermined & 0.0 & $0.0 \pm 0.0$ & $0.5 \pm 0.4$ & $0.0 \pm 0.0$ & $0.0 \pm 0.0$ \\
\hline
\end{tabular}

Dam and Lopes, 2003; Chen et al., 2010; Hauss et al., 2013). However, some differences appeared for meroplankton larva, probably explained by the larval stage. In contrast, the highest trophic positions were found for Labidocera spp., Eucheta spp., Acartia spp., siphonophora and chaetognaths (Tromelin island, TO), as reported by many studies (Turner, 1984; Gifford and Dagg, 1988; Hauss et al.,
2013).

For the same species found in different stations, inside or outside the Mozambique Channel, the calculated trophic positions of metazooplankton taxa showed similar values whereas $\partial^{15} \mathrm{~N}$ signatures were different between the sites. Thus, these species were probably characterized by the same diet (same TP) whatever 
Table 3

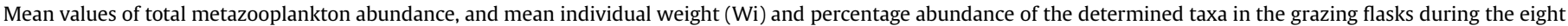

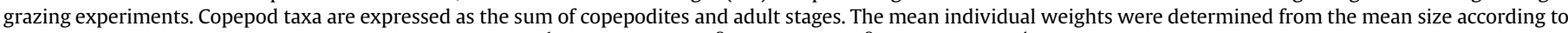

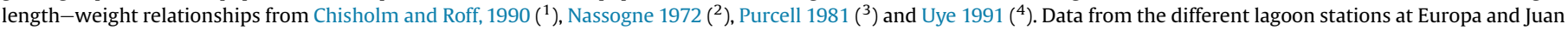
de Nova (EL and JL) are averaged in order to have a mean value per lagoon.

\begin{tabular}{|c|c|c|c|c|c|c|c|c|c|}
\hline & Wi $\mu \mathrm{gC}$ & EO & EL & BO & $\mathrm{JL}$ & JO & GO & TO & ML \\
\hline Total number (ind $500 \mathrm{ml}^{-1}$ ) & & 24.7 & 50.3 & 34.5 & 30.7 & 45.0 & 25.0 & 26.3 & 38.0 \\
\hline Copepoda \% & & 98.6 & 94.6 & 97.1 & 30.4 & 97.8 & 70.2 & 100.0 & 79.8 \\
\hline Nauplii & $0.3^{4}$ & 2.8 & 0.4 & 2.9 & 3.3 & 3.3 & 7.0 & 5.1 & 0.0 \\
\hline Paracalanus spp. & $5.3^{1}$ & 28.2 & 16.6 & 29.0 & 8.7 & 43.3 & 19.3 & 6.3 & 42.1 \\
\hline Clausocalanus spp. & $6.4^{1}$ & 1.4 & 0.0 & 0.0 & 0.0 & 2.2 & 0.0 & 0.0 & 0.0 \\
\hline Acartia spp. & $3.9^{1}$ & 0.0 & 0.0 & 1.4 & 2.2 & 16.7 & 5.3 & 16.5 & 21.1 \\
\hline Centropages spp. & $5.6^{1}$ & 0.0 & 0.4 & 0.0 & 0.0 & 0.0 & 0.0 & 0.0 & 0.0 \\
\hline Candacia varicans & $23.9^{1}$ & 1.4 & 0.9 & 1.4 & 1.1 & 0.0 & 0.0 & 0.0 & 0.0 \\
\hline Eucalanus sp. & $113.2^{1}$ & 0.0 & 0.0 & 4.3 & 0.0 & 0.0 & 0.0 & 0.0 & 0.0 \\
\hline Euchaeta sp. & $172.7^{1}$ & 1.4 & 0.0 & 0.0 & 0.0 & 1.1 & 0.0 & 0.0 & 0.0 \\
\hline Calocalanus sp. & $5.6^{1}$ & 1.4 & 0.0 & 0.0 & 0.0 & 0.0 & 0.0 & 0.0 & 0.0 \\
\hline Rhincalanus sp. & $113.2^{1}$ & 0.0 & 0.0 & 1.4 & 0.0 & 0.0 & 0.0 & 0.0 & 0.0 \\
\hline Pseudodiaptomus sp. & $16.9^{1}$ & 0.0 & 0.9 & 1.4 & 0.0 & 0.0 & 1.8 & 0.0 & 0.9 \\
\hline Pontellina sp. & $16.9^{1}$ & 1.4 & 0.0 & 0.0 & 0.0 & 0.0 & 0.0 & 0.0 & 0.0 \\
\hline Ctenocalanus sp. & $16.9^{1}$ & 0.0 & 0.0 & 0.0 & 0.0 & 0.0 & 0.0 & 1.3 & 0.0 \\
\hline Lucicutia sp. & $23.9^{1}$ & 0.0 & 0.0 & 0.0 & 0.0 & 0.0 & 0.0 & 1.3 & 0.0 \\
\hline Unidentified calanoid & $5.6^{1}$ & 2.8 & 1.3 & 0.0 & 3.3 & 2.2 & 0.0 & 2.5 & 1.8 \\
\hline Oncaea spp. & $4.9^{1}$ & 7.0 & 34.1 & 23.2 & 3.3 & 6.7 & 1.8 & 2.5 & 4.4 \\
\hline Oithona spp. & $3.0^{1}$ & 40.8 & 36.3 & 14.5 & 5.4 & 7.8 & 10.5 & 11.4 & 5.3 \\
\hline Corycaeus spp. & $2.8^{1}$ & 5.6 & 0.4 & 13.0 & 2.2 & 12.2 & 12.3 & 40.5 & 0.0 \\
\hline Sapphirina sp. & $37.3^{1}$ & 0.0 & 0.0 & 0.0 & 0.0 & 0.0 & 0.0 & 1.3 & 0.0 \\
\hline Copilia sp. & $16.9^{1}$ & 0.0 & 0.0 & 2.9 & 0.0 & 1.1 & 0.0 & 1.3 & 1.8 \\
\hline Euterpina sp. & $1.1^{1}$ & 0.0 & 0.4 & 0.0 & 0.0 & 0.0 & 0.0 & 0.0 & 0.0 \\
\hline Tisbe sp. & $1.9^{1}$ & 0.0 & 0.9 & 0.0 & 0.0 & 0.0 & 0.0 & 0.0 & 0.0 \\
\hline Macrosetella sp. & $1.9^{1}$ & 4.2 & 1.3 & 1.4 & 1.1 & 1.1 & 12.3 & 10.1 & 2.6 \\
\hline Harpaticoïd unidentified spp. & $1.9^{1}$ & 0.0 & 0.4 & 0.0 & 0.0 & 0.0 & 0.0 & 0.0 & 0.0 \\
\hline Other holoplankton \% & & 0.0 & 0.4 & 0.0 & 5.4 & 0.0 & 1.8 & 0.0 & 0.0 \\
\hline Amphipoda & $19.8^{3}$ & 0.0 & 0.4 & 0.0 & 5.4 & 0.0 & 1.8 & 0.0 & 0.0 \\
\hline Gelatinous \% & & 1.4 & 1.3 & 0.0 & 59.8 & 1.1 & 8.8 & 0.0 & 19.3 \\
\hline Salps and doliolids & $48.0^{2}$ & 0.0 & 0.4 & 0.0 & 0.0 & 1.1 & 0.0 & 0.0 & 0.0 \\
\hline Chaetognaths & $14.2^{3}$ & 0.0 & 0.4 & 0.0 & 0.0 & 0.0 & 0.0 & 0.0 & 0.0 \\
\hline Appendicularia & $2.6^{2}$ & 0.0 & 0.0 & 0.0 & 59.8 & 0.0 & 8.8 & 0.0 & 19.3 \\
\hline Siphonophora & $9.9^{2}$ & 1.4 & 0.4 & 0.0 & 0.0 & 0.0 & 0.0 & 0.0 & 0.0 \\
\hline Larva (meroplankton) \% & & 0.0 & 3.6 & 2.9 & 4.3 & 1.1 & 19.3 & 0.0 & 0.9 \\
\hline Polychaetes & $4.0^{2}$ & 0.0 & 0.9 & 0.0 & 0.0 & 0.0 & 0.0 & 0.0 & 0.0 \\
\hline Decapod & $55.6^{3}$ & 0.0 & 2.7 & 1.4 & 3.3 & 0.0 & 19.3 & 0.0 & 0.0 \\
\hline Fish larvae & $11.8^{2}$ & 0.0 & 0.0 & 1.4 & 0.0 & 0.0 & 0.0 & 0.0 & 0.9 \\
\hline Undetermined & $4.0^{2}$ & 0.0 & 0.0 & 0.0 & 1.1 & 1.1 & 0.0 & 0.0 & 0.0 \\
\hline
\end{tabular}

the locations: for example Oncea spp., Corycaeus spp. and appendicularia. In contrast, the $\partial^{15} \mathrm{~N}$ signature and, thus trophic position, was very variable for Oithona spp., which presented a very low TP in the station for the islands in the Mozambique Channel compared to Tromelin (TO). The change in TP and $\partial^{15} \mathrm{~N}$ signature would be manifested in difference spatial diet of Oithona spp.. The POM and metazooplankton for Tromelin Island station had higher values of $\delta^{15} \mathrm{~N}$ than the POM and similar taxa at other stations in the Mozambique Channel. At this oceanic station outside the Mozambique Channel (TO), Bouvy et al. (2016) found the highest ratio between heterotrophic and autotrophic microorganisms suggesting largely a heterotrophic material available for metazooplankton. Therefore, previous studies have suggested that a substantial part of the standing stock of chlorophyll- $a$ in oligotrophic tropical and subtropical oceans can be attributed to the diazotroph Trichodesmium spp. (e.g. Sellner, 1997; Capone et al., 1997). Stable isotopic analysis of $N\left(\delta^{15} N\right)$ has shown that the $N$ fixed by diazotrophs is isotopically 'light' because the origin is atmospheric nitrogen (whose $\delta^{15} \mathrm{~N}$ by definition is $0 \%$ ). Hence, pelagic food webs in which diazotrophic cyanobacteria proliferate have very different isotopic ratios from food webs without diazotrophs, where the $\delta^{15} \mathrm{~N}$ is normally higher (5-15\%; Owens, 1987). In our study, analysis of microphytoplankton indicated the presence of Trichodesmium spp. in the stations inside the
Mozambique Channel and its total absence outside the channel (Tromelin Island station). However, the $\delta^{15} \mathrm{~N}$ signatures of POM at sites from the Mozambique Channel were not characterized by low $\delta^{15} \mathrm{~N}$ values even if Trichodesmium was present. Our sampling method (subsample of water from Niskin bottle) was certainly not enough appropriate as reported by Chang (2000), where subsampling from a Go-Flo bottle contributes $90 \%-94 \%$ of the total variance observed in abundance revealing a heterogeneous distribution of Trichodesmium trichomes in a sampling bottle. However, the $\delta^{15} \mathrm{~N}$ signature of some metazooplankton taxa as chaetognaths, Acartia spp., Eucheta spp., Clausocalanus spp., Oithona spp. and salps and doliolids presented lower TPs inside the Mozambique Channel compared to the outside Channel (Tromelin island). This observation indicated a different spatial diet for these organisms and probably a trophic transfer (direct or indirect) of diazotrophic nitrogen (from Trichodesmium spp.) to metazooplankton in the Mozambique Channel. It can, therefore, be concluded that a plankton food web was probably preferentially based on Trichodesmium spp. in marine systems in the Mozambique Channel but not for Tromelin Island. In the future studies, patterns in stable $\mathrm{N}$ isotope ratios of amino acids in metazooplankton and in Trichodesmium, as proposed by McClelland et al. (2003), will permit to definitively prove that diazotrophs are the source of the planktonic web in the 
Table 4

Metazooplankton $\delta^{15} \mathrm{~N}$ POM-based trophic position (TPs): mean and SD. TO: Tromelin; EL: Europa lagoon; GO: Glorieuses ocean; GL: Glorieuses lagoon; ML: Mayotte; JL: Juan de Nova lagoon. Data from the different lagoon stations at Europa, Juan de Nova and Glorieuses (EL, JL and GL) are averaged in order to have a mean value per lagoon.

\begin{tabular}{|c|c|c|}
\hline Copepoda & Mean TP & SD TP \\
\hline Acartia & 0.908 & 0.343 \\
\hline Acartia TO & 1.608 & \\
\hline Corycaeus & 1.051 & 0.554 \\
\hline Corycaeus TO & 1.026 & \\
\hline Eucheta & 0.919 & 0.186 \\
\hline Eucheta TO & 1.510 & \\
\hline Oithona EL & -0.718 & \\
\hline Oithona GO & -1.751 & \\
\hline Oithona TO & 0.715 & \\
\hline Oncaea & -0.114 & 0.313 \\
\hline Oncaea GL & 1.305 & \\
\hline Oncaea TO & -0.113 & \\
\hline Clausocalanus & 0.831 & 0.753 \\
\hline Clausocalanus TO & 1.229 & \\
\hline Pontellidae & 0.005 & \\
\hline Temora & 0.199 & 0.082 \\
\hline Temora ML & 1.067 & \\
\hline Tortanus insularis & 1.289 & \\
\hline Undinula & 0.820 & 0.029 \\
\hline Calanus & 0.568 & \\
\hline Eucalanus & 0.213 & \\
\hline Labidocera & 1.908 & \\
\hline Macrosetella & 0.042 & 0.240 \\
\hline Paracalanus & 0.491 & 0.431 \\
\hline \multicolumn{3}{|l|}{ Gelatinous } \\
\hline Appendicularia & 0.922 & 0.303 \\
\hline Appendicularia TO & 0.889 & \\
\hline Chaetognaths & 1.189 & 0.496 \\
\hline Chaetognaths TO & 2.027 & \\
\hline Salps and doliolids & 0.483 & \\
\hline Salps and doliolids TO & 1.330 & \\
\hline Siphonophora & 1.707 & \\
\hline \multicolumn{3}{|l|}{ Larva (meroplankton) } \\
\hline Crab larva & 0.615 & \\
\hline Decapode larva GL & 1.012 & \\
\hline Decapode larva GO & 0.326 & \\
\hline Decapode larva TO & 0.952 & \\
\hline Megalope larva & 0.428 & \\
\hline Shrimp larva & 0.401 & 0.280 \\
\hline Shrimp JL & 0.914 & \\
\hline Echinoderm larva & 0.339 & \\
\hline Fish larva & 0.388 & \\
\hline Fish larva EL & 1.697 & \\
\hline Polychaetes larva & 1.368 & \\
\hline
\end{tabular}

Mozambique Channel.

In this study, the trophic link with Trichodesmium spp. was particularly close for the copepods Oncaea spp. and Macrosetella sp. (see Fig. 6). So far as we are aware, a direct trophic link between Trichodesmium spp. and Oncaea spp. has never been established. However, Oncaea species were shown to have a predominantly omnivorous/detritivorous diet (Atkinson, 1998) being able to use their sharp maxillipeds to catch large prey, such as chaetognaths (Go et al., 1998) and appendicularian houses (Nishibe et al., 2015). Thus, the detritus and aggregates associated with Trichodesmium spp. and even the large trichomes should benefit this copepod. The association of Macrosetella gracilis with the colonial cyanobacterium Trichodesmium spp. has been shown in several studies. This pelagic harpacticoid copepod is known to use Trichodesmium spp. as a physical substrate for juvenile development and/or as a food source, being immune to cyanobacterial toxins harmful to other species of copepods (O'Neil and Roman, 1994; Eberl and Carpenter, 2007). Its association with a buoyant colonial cyanobacterium is interpreted as a successful way of living within the plankton, whereas most harpacticoids are benthic (O'Neil, 1998). In this study, when preparing the metazooplankton sets for grazing experiments or for isotopic analyses, a high abundance of Macrosetella sp., particularly ovigerous females, associated with Trichodesmium spp. trichomes was observed.

\subsection{Grazing of metazooplankton on phytoplankton}

In our experiment, the largest potential phytoplankton preys (as diatoms or large dinoflagellates) were not considered, leading to a possible underestimation of total ingestion rates. However the measured daily ratios reached very high values (up to $360 \%$ of carbon body weight per day) as compared to literature data (Mauchline, 1998) suggesting that this bias should be minor. The experiments showed a positive relationship between ingestion rate and natural food concentration (total autotrophic microorganisms), indicating that food could be a limiting factor for metazooplankton in the area. This is fairly standard in such oligotrophic environments (chlorophyll concentration $<0.7 \mu \mathrm{g} \mathrm{l}^{-1}$ ) characterized by the dominance of picoplanktonic cells not easily accessible for most filter feeders, and particularly for copepods (high abundance in the sites studied) known to feed mostly on nanoplankton (Mauchline, 1998). They clearly showed that metazooplankton tended not to prey on picophytoplankton, despite its dominance in the prey assemblages, and preferred nanophytoplankton. Furthermore, there were few typical picoplankton grazers. For example, salps and doliolids are known to feed efficiently on picoplankton (Madin and Kremer, 1995) but none were found in the samples except for the Glorieuses ocean station (GO). These features also suggest the potential role of micro-heterotrophs (ciliates and heterotrophic nanoflagellates, not considered in this study) as part of the metazooplankton diet, as this type of prey can be ingested in large quantities when stocks of phytoplankton are depleted (Loder et al., 2011; Pagano et al., 2012).

Grazing by metazooplankton on autotrophic microorganisms had very little effect, representing less than $3 \%$ of the phytoplankton stocks per day. Metazooplankton grazing has already been reported to have little effect on phytoplankton in lowchlorophyll zones within the inter-tropical zone, as for example in the equatorial Pacific Ocean (Champalbert et al., 2003). However, in these low-chlorophyll areas, grazing may have a strong effect on micro-heterotrophs, sometimes leading to increased biomass of nanoplankton (Schnetzer and Caron, 2005). Around the Iles Eparses, high grazing pressure on micro-heterotrophs cannot be excluded, but the low proportion of nanophytoplankton excludes the possibility of such cascading effects.

\subsection{Conclusion}

Overall, based on one single survey in April combined with several grazing experiments, these results showed that the hydrodynamics of the Mozambique Channel created particular conditions with a high abundance of Trichodesmium spp. and a direct or indirect trophic transfer of diazotrophic nitrogen to metazooplankton. On the other hand, the absence of Trichodesmium spp. and mollusks (Pteropods) in the ocean waters near Tromelin Island (outside the Mozambique Channel) created a particular trophic food web with the highest $\delta^{15} \mathrm{~N}$ signatures. Furthermore, Juan de Nova Island can be considered as being the most affected by human activities, with a trophic state resembling that of the anthropized Mayotte lagoon. Phytoplankton may be a limiting factor for metazooplankton throughout all the "Iles Eparses". 


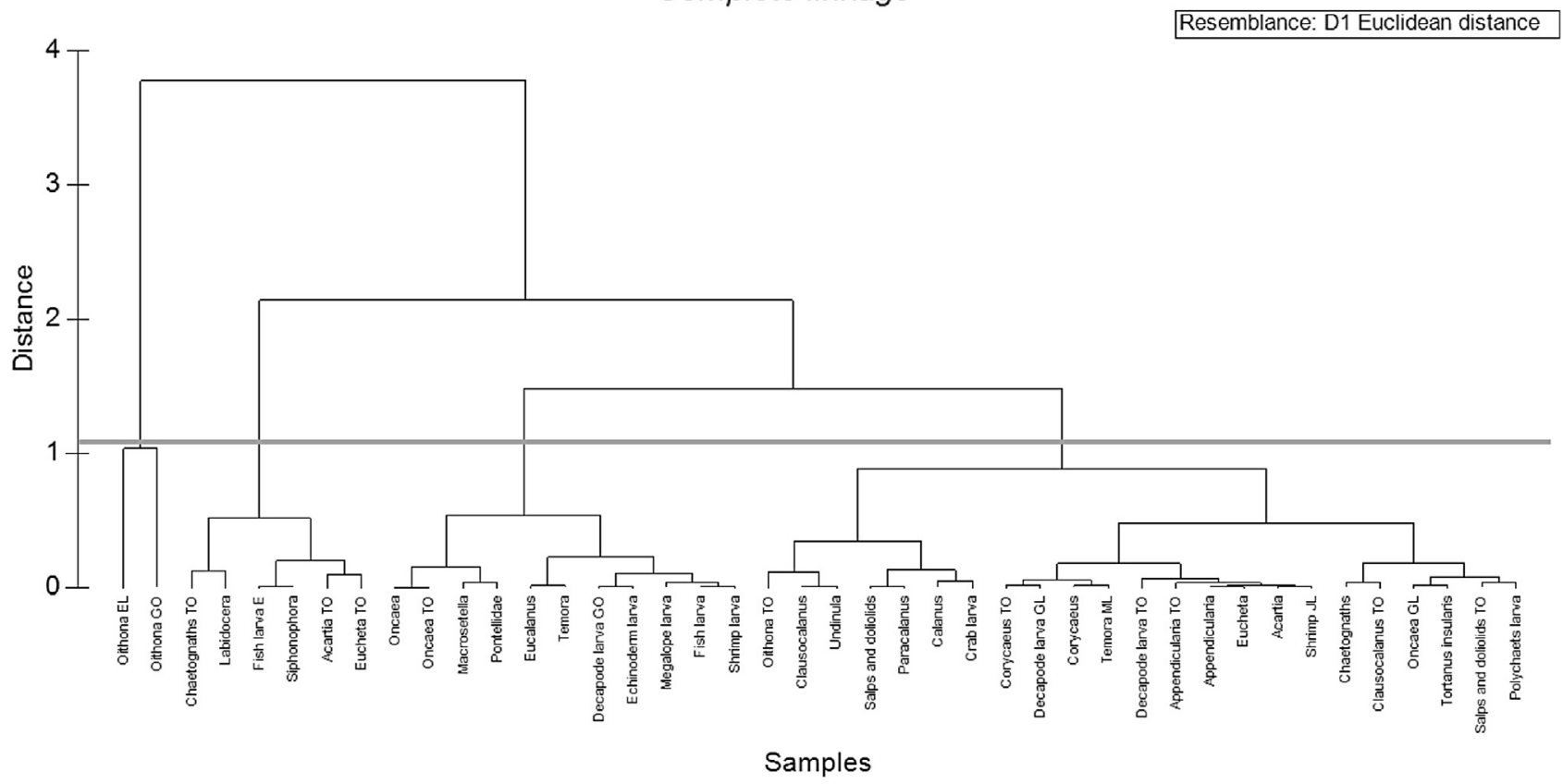

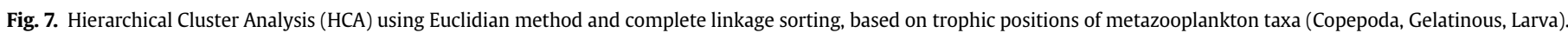
Data from the different lagoon stations at Europa and Juan de Nova: (EL and JL) are averaged in order to have a mean value per lagoon.

\section{Acknowledgments}

This research was supported by France's "Iles Eparses" Program (2011-2013) managed by CNRS-InEE (Institut Ecologie et Environnement) with the financial support of CNRS-InEE, CNRS-INSU (Institut National des Sciences de l'Univers), IRD (Institut de Recherche pour le Développement), AAMP (Agence des Aires Marines Protégées), and the logistic support of TAAF (Terres Australes et Antarctiques Françaises). Our thanks go out to the TAAF staff (especially Cedric Marteau) and the crew of the Marion Dufresne whose help contributed largely to the success of the "2011 Eparses" expedition. We should also like to thank Pascale Chabanet and his team (BIORECIE) for their help in collecting water samples and the stable isotope platform in the LIENSs laboratory.

\section{References}

Acuna, J.L., Deibel, D., Saunders, P.A., Booth, B., Hatfield, E., Klein, B., Mei, Z.P., Rivkin, R., 2002. Phytoplankton ingestion by appendicularians in the North Water. Deep Sea Res. Part II Top. Stud. Oceanogr. 49, 5101-5115.

Alldredge, A.L., King, J.M., 2009. Near-surface enrichment of zooplankton over a shallow back reef: implications for coral reef food webs. Coral Reefs 28, 895-908.

Ara, K., 2004. Temporal variability and production of the planktonic copepod community in the Cananeia Lagoon estuarine system, Sao Paulo, Brazil. Zool, Stud. 43, 179-186.

Atkinson, A., 1998. Life cycle strategies of epipelagic copepods in the Southern Ocean. J. Mar. Syst. 15, 289-311.

Attayde, J.L., Bozelli, R.L., 1998. Assessing the indicator properties of zooplankton assemblages to disturbance gradients by canonical correspondence analysis Can. J. Fish. Aquat. Sci. 55, 1789-1797.

Beaugrand, G., 2003. Long-term changes in copepod abundance and diversity in the north-east Atlantic in relation to fluctuations in the hydroclimatic environment. Fish. Oceanogr. 12, 270-283.

Bode, A., Alvarez Ossorio, M.T., Carrera, P., Lorenzo, J., 2004. Reconstruction of trophic pathways between plankton and the North Iberian sardine (Sardina pilchardus) using stable isotopes. Sci. Mar. 68, 165-178.

Bouvy, M., Got, P., Domaizon, I., Pagano, M., Leboulanger, C., Bouvier, C., Carré, C., Roques, C., Dupuy, C., 2016. Plankton communities in the five Iles Eparses (Western Indian Ocean) considered to be pristine ecosystems. Acta Oecol. 72, $9-20$.

Bozec, Y.M., Gascuel, D., Kulbicki, M., 2004. Trophic model of lagoonal communities in a large open atoll (Uvea, Loyalty islands, New Caledonia). Aquat. Living
Resour. 17, 151-162.

Calbet, A., Trepat, I., Almeda, R., Salo, V., Saiz, E., Movilla, J.I., Alcaraz, M., Yebra, L., Simo, R., 2008. Impact of micro- and nanograzers on phytoplankton assessed by standard and size-fractionated dilution grazing experiments. Aquat. Microb. Ecol. 50, 145-156.

Capone, D.G., Zehr, J.P., Paerl, H.W., Bergman, B., Carpenter, E.J., 1997. Trichodesmium, a globally significant marine cyanobacterium. Science 276, 1221-1229.

Caparroy, P., Perez, M.T., Carlotti, F., 1998. Feeding behaviour of Centropages typicus in calm and turbulent conditions. Mar. Ecol. Prog. Ser. 168, 109-118.

Champalbert, G., Neveux, J., Gaudy, R., Le Borgne, R., 2003. Diel variations of copepod feeding and grazing impact in the high-nutrient, low-chlorophyll zone of the equatorial Pacific Ocean (0 degrees; 3degrees S, 180 degrees). J. Geophys. Res. Oceans 108, 1-10.

Chang, J., 2000. Precision of different methods used for estimating the abundance of the nitrogen-fixing marine cyanobacterium, Trichodesmium Ehrenberg. J. Exp. Mar. Biol. Ecol. 245, 215-224.

Charpy, L., Blanchot, J., 1998. Photosynthetic picoplankton in French Polynesian atoll lagoons: estimation of taxa contribution to biomass and production by flow cytometry. Mar. Ecol. Prog. Ser. 162, 57-70.

Chen, M.R., Ka, S., Hwang, J.S., 2010. Diet of the copepod Calanus sinicus Brodsky, 1962 (Copepoda, Calanoida, Calanidae) in northern coastal waters of Taiwan during the northeast monsoon period. Crustaceana 83, 851-864.

Chisholm, L.A., Roff, J.C., 1990. Size-weight relationships and biomass of tropical off Kingston, Jamaica. Mar. Biol. 106, 71-77.

Chouvelon, T., Chappuis, A., Bustamante, P., Lefebvre, S., Mornet, F., Guillou, G. Violamer, L., Dupuy, C., 2014. Trophic ecology of European sardine Sardina pilchardus and European anchovy Engraulis encrasicolus in the Bay of Biscay (north-east Atlantic) inferred from $\delta{ }^{13} \mathrm{C}$ and $\delta{ }^{15} \mathrm{~N}$ values of fish and identified mesozooplanktonic organisms. J. Sea Res. 85, 277-291.

Conway, D.V.P., White, R.G., Hugues-Dit-Ciles, J., Gallienne, C.P., Robins, D.B., 2003. Guide to the Coastal and Surface Zooplankton of the South-western Indian Ocean. DEFRA Darwin Initiative Zooplankton Programme, Version 1, vol. 15 Marine Biological Association of the United Kingdom Occasional Publications, Plymouth.

Dam, H.G., Lopes, R.M., 2003. Omnivory in the calanoid copepod Temora longicornis: feeding, egg production and egg, hatching rates. J. Exp. Mar. Biol. Ecol. 292, 119-137.

Eberl, R., Carpenter, E.J., 2007. Association of the copepod Macrosetella gracilis with the cyanobacterium Trichodesmium spp. in the North Pacific Gyre. Mar. Ecol. Prog. Ser. 333, 205-212.

Flombaum, P., Gallegos, J.L., Gordillo, R.A., Rincon, J., Zabala, L.L., et al., 2013. Present and future global distributions of the marine Cyanobacteria Prochlorococcus and Synechococcus. Proc. Natl. Acad. Sci. 110, 9824-9829.

Gaudy, R., Bianchi, M., Pagano, M., Soto, Y., 1996. Cross frontal variability in hydrological and biological structures observed in a river plume area (Rhone mouth, NW Mediterranean Sea). Hydrobiologia 324, 131-140.

Gerber, R.P., 1981. Species composition and abundance of lagoon zooplankton at Enewetak atoll, Marshall Isalands. Atoll Res. Bull. 247, 1-22. 
Gibson, D.M., Paffenhöfer, G.A., 2000. Feeding and growth rates of the doliolid Dolioletta gegenbauri Uljanin (Tunicata, Thaliacea). J. Plankton Res. 22, 1485-1500.

Gifford, D.J., Dagg, M.J., 1988. Feeding of the estuarine copepod Acartia tonsa Dana carnivory vs. herbivory in natural microplankton assemblages. Bull. Mar. Sci. 43, 458-468.

Go, Y.B., Oh, B.C., Terazaki, M., 1998. Feeding behavior of the poecilostomatoid copepods Oncaea spp. on chaetognaths. J. Mar. Syst. 15, 475-482.

Gourbesville, P., Thomassin, B.A., 2000. Coastal environment assessment procedure for sustainable wastewater management in tropical islands: the Mayotte example. Ocean. Coast. Manag. 43, 997-1014.

Hamner, W.M., Colin, P.L., Hamner, P.P., 2007. Export-import dynamics of zooplankton on a coral reef in Palau. Mar. Ecol. Prog. Ser. 334, 83-92.

Harris, R.P., Wiebe, P., Lenz, J., Skjoldal, H.R., Huntley, M., 2000. Zooplankton Methodology Manual. Academic Press, London.

Hauss, H., Franz, J.M.S., Hansen, T., Struck, U., Sommer, U., 2013. Relative inputs of upwelled and atmospheric nitrogen to the eastern tropical North Atlantic food web: spatial distribution of $\delta^{15} \mathrm{~N}$ in mesozooplankton and relation to dissolved nutrient dynamics. Deep Sea Res. Part I Oceanogr. Res. Pap. 75, 135-145.

Hosie, G.W., Cochran, T.G., 1994. Mesoscale distribution patterns of macrozooplankton communities in Prydz Bay, Antarctica - January to February 1991. Mar. Ecol. Prog. Ser. 106, 21-39.

Huggett, J.A., 2014. Mesoscale distribution and community composition of zooplankton in the Mozambique Channel. Deep Sea Res. Part II Top. Stud. Oceanogr. 100, 119-135.

Irigoien, X., Head, R.N., Harris, R.P., Cummings, D., Harbour, D., Meyer-Harms, B., 2000. Feeding selectivity and egg production of Calanus helgolandicus in the English Channel. Limnol. Oceanogr. 45, 44-54.

Jacob, U., Mintenbeck, K., Brey, T., Knust, R., Beyer, K., 2005. Stable isotope food web studies: a case for standardized sample treatment. Mar. Ecol. Prog. Ser. 287, $251-253$.

Kennedy, H., Thomas, D.N., Kattner, G., Haas, C., Diekmann, S., 2002. Particulate organic matter in Antarctic summer sea ice: concentration and stable isotopic composition. Mar. Ecol. Prog. Ser. 238, 1-13.

Kiørboe, T., 1998. Population regulation and role of mesozooplankton in shaping marine pelagic food webs. Hydrobiologia 363, 13-27.

Kiørboe, T. Mohlenberg, F., Hamburger, K., 1985. Bioenergetics of the planktonic copepod Acartia tonsa: relation between feeding, egg production and respiration, and the composition of specific dynamic action. Mar. Ecol. Prog. Ser. 26 85-97.

Kürten, B., Painting, S.J., Struck, U., Polunin, N.V.C., Middelburg, J.. 2013. Tracking seasonal changes in North Sea zooplankton trophic dynamics using stable isotopes. Biogeochemistry 113, 167-187.

Lamont, T. Barlow, R.G., Morris, T., van den Berg, M.A., 2014. Characterisation of mesoscale features and phytoplankton variability in the Mozambique Channel. Deep Sea Res. Part II Top. Stud. Oceanogr. 100, 94-105.

Le Corre, M., Safford, R.J., 2001. La Réunion and Iles Eparses 11, 693-702. In: Fishpool, L., Evans, M. (Eds.), Important Bird Areas in Africa and Associated Islands. Priority Sites for Conservation. Birdlife Conservation Series.

Loder, M.G.J., Meunier, C., Wiltshire, K.H., Boersma, M., Aberle, N., 2011. The role of ciliates, heterotrophic dinoflagellates and copepods in structuring spring plankton communities at Helgoland Roads, North Sea. Mar. Biol. 158, 1551-1580.

Lombard, F., Renaud, F., Sainsbury, C., Sciandra, A., Gorsky, G., 2009. Appendicularian ecophysiology I Food concentration dependent clearance rate, assimilation efficiency, growth and reproduction of Oikopleura dioica. J. Mar. Syst. 78, $606-616$.

Madin, L.P., Kremer, P., 1995. Determination of the filter-feeding rates of salps (Tunicata, Thaliacea). Ices J. Mar. Sci. 52, 583-595.

Mauchline, J., 1998. The biology of Calanoid copepods. In: Blaxter, J.H.S., Southward, A.J., Tyler, P.A. (Eds.), Advances in Marine Biology. Academic Press, London, p. 710.

McClelland, J.W., Holl, C.M., Montoya, J.P., 2003. Relating low $\delta^{15} \mathrm{~N}$ values of zooplankton to N2-fixation in the tropical North Atlantic: insights provided by stable isotope ratios of amino acids. Deep Sea Res. 50, 849-861.

McKinnon, A.D., Klumpp, D.W., 1998. Mangrove zooplankton of North Queensland, Australia I. Plankton community structure and environment. Hydrobiologia $362,127-143$.

Michener, R.H., Kaufman, L., 2007. Stable isotope ratios as tracers in marine food webs: an update. In: Michener, R., Lajtha, K. (Eds.), Stable Isotopes in Ecology and Environmental Science. Blackwell, Malden, pp. 238-282.

Minagawa, M., Wada, E., 1984. Stepwise enrichment of $15 \mathrm{~N}$ along food chains: further evidence and the relation between d15N and animal age. Geochim. Cosmochim. Acta 48, 1135-1140.

Nassogne, A., 1972. Etudes préliminaires sur le rôle du zooplancton dans la constitution et le transfert de la matière organique au sein de la chaîne alimentaire marine en Mer Ligure. Publ. n"B.I.0. 187 Direction Biologie EURATOM, p. 238.

Nishibe, Y., Takahashi, K., Ichikawa, T., Hidaka, K., Kurogi, H., Segawa, K., Saito, H. 2015. Degradation of discarded appendicularian houses by oncaeid copepods. Limnol. Oceanogr. 60, 967-976.

O'Neil, J.M., 1998. The colonial cyanobacterium Trichodesmium as a physical and nutritional substrate for the harpacticoid copepod Macrosetella gracilis. J. Plankton Res. 20, 43-59.

O'Neil, J.M., Roman, M.R., 1994. Ingestion of the cyanobacterium Trichodesmium spp. by pelagic harpacticoid copepods Macrosetella, Miracia and Oculostella. Hydrobiologia 293, 235-240.

Owens, N.J.P., 1987. Natural variations in ${ }^{15} \mathrm{~N}$ in the marine environment. Adv. Mar. Biol. 24, 389-451.

Paffenhöfer, G.A., Strickler, J.R., Alcaraz, M., 1982. Suspension-feeding by herbivorous calanoid copepods: a cinematographic study. Mar. Biol. 67, 193-199.

Pagano, M., Champalbert, G., Aka, M., Kouassi, E., Arfi, R., Got, P., Troussellier, M., Eh, N.D., Corbin, D., Bouvy, M., et al., 2006. Herbivorous and microbial grazing pathways of metazooplankton in the Senegal River Estuary (West Africa). Estuar. Coast. Shelf Sci. 67, 369-381.

Pagano, M., 2008. Feeding of tropical cladocerans (Moina micrura, Diaphanosoma excisum) and rotifer (Brachionus calyciflorus) on natural phytoplankton : effect of phytoplankton size-structure. J. Plankton Res. 30, 401-414.

Pagano, M., Sagarra, P.B., Champalbert, G., Bouvy, M., Dupuy, C., Thomas, Y., Charpy, L., 2012. Metazooplankton communities in the Ahe atoll lagoon (Tuamotu Archipelago, French Polynesia): spatio-temporal variations and trophic relationships. Mar. Pollut. Bull. 65, 538-548.

Partensky, F., Hess, W.R., Vaulot, D., 1999. Prochlorococcus, a marine photosynthetic prokaryote of global significance. Microbiol. Mol. Biol. Rev. 63, 106-127.

Pelegri, S.P., Dolan, J.R., Rassoulzadegan, F.U., 1999. Use of high temperature catalytic oxidation (HTCO) to measure carbon content of microorganisms. Aquat. Microb. Ecol. 16, 273-280.

Peterson, B.J., Fry, B., 1987. Stable isotopes in ecosystem studies. Annu. Rev. Ecol. Syst. 18, 293-320.

Pollack, J.B., Mroch, R.M., Feller, R.J., 2008. Juvenile white shrimp Litopenaeus setiferus predation on macrobenthic and zooplanktonic prey. J. Shellfish Res. 27, $1247-1253$.

Pont, D., 1995. Le zooplancton herbivore dans les chaînes alimentaires pélagiques. In: Pourriot, R., Meybeck, M. (Eds.), Limnologie Générale, Collection d'Ecologie. Masson, Paris, pp. 515-540.

Poulet, S.A., 1983. Factors controlling utilization of non-algal diet by particle-grazing copepods. A review. Oceanol. Acta 6, 221-234.

Purcell, J.E., 1981. Dietary composition and diel feeding patterns of epipelagic siphonophores. Mar. Biol. 65, 83-90.

Razouls, C., de Bovée, F., Kouwenberg, J., Desreumaux, N., 2005-2014. Diversité et répartition géographique chez les Copépodes planctoniques marins. http:// copepodes.obs-banyuls.fr.

Rassoulzadegan, F., Laval-Peuto, M., Sheldon, R.W., 1988. Partition of the food ration of marine ciliates between pico and nanoplankton. Hydrobiologia 159, 75-88.

Schnetzer, A., Caron, D.A., 2005. Copepod grazing impact on the trophic structure of the microbial assemblage of the San Pedro Channel, California. J. Plankton Res. 27, 959-971.

Sellner, K.G., 1997. Physiology, ecology, and toxic properties of marine cyanobacteria blooms. Limnol. Oceanogr. 42, 1089-1104.

Sommer, F., Sommer, U., 2004. $\delta^{15} \mathrm{~N}$ signatures of marine mesozooplankton and seston size fractions in Kiel Fjord, Baltic Sea. J. Plankton Res. 26, 495-500.

Spinelli, M.L., Pajaro, M., Martos, P., Esnal, G.B., Sabatini, M., Capitanio, F.L., 2012. Potential zooplankton preys (Copepoda and Appendicularia) for Engraulis anchoita in relation to early larval and spawning distributions in the Patagonian frontal system (SW Atlantic Ocean). Sci. Mar. 76, 39-47.

Stoecker, D.K., Egloff, D.A., 1987. Predation by Acartia tonsa Dana on planktonic ciliates and rotifers. J. Exp. Mar. Biol. Ecol. 110, 53-68.

Stoecker, D.K., Sanders, N.K., 1985. Differential grazing by Acartia tonsa on a dinoflagellate and a tintinnid. J. Plankton Res. 7, 85-100.

Suzuki, K., Nakamura, Y., Hiromi, J., 1999. Feeding by the small calanoid copepod Paracalanus sp. on heterotrophic dinoflagellates and ciliates. Aquat. Microb. Ecol. 17, 99-103.

Tiselius, P., 1989. Contribution of loricate ciliates to the diet of Acartia clausi and Centropages hamatus in coastal waters. Mar. Ecol. Prog. Ser. 56, 49-56.

Tregouboff, G., Rose, M., 1957. In: Manuel de planctonologie méditerranéenne. Paris.

Turner, J.T., 1984. Zooplankton feeding ecology: contents of fecal pellets of the copepods Acartia tonsa and Labidocera aestiva from continental shelf waters near the mouth of the Mississippi River. Mar. Ecol. 5, 265-282.

Uye, S.I., 1982. Length-weight relationships of important zooplankton from the Inland Sea of Japan. J. Oceanogr. Soc. Jpn. 38, 149-158.

Uye, S.I., 1991. Temperature-dependent development and growth of the Planktonic copepod Paracalanus sp. in the laboratory. In: Proceedings of the Fourth International Conference on Copepoda; Bulletin of Plankton Society of Japan: Special Volume, pp. 627-636.

Vanderploeg, H.A., Scavia, D., 1979. Two electivity indices for feeding with special reference to zooplankton grazing. J. Fish. Res. Board Can. 36, 362-365.

Vargas, C.A., Gonzáles, H.E., 2004. Plankton community structure and carbon cycling in a coastal upwelling system. I. Bacteria, microprotozoans and phytoplankton in the diet of copepods and appendicularians. Aquat. Microb. Ecol. 34, 151-164.

Verity, P., Robertson, C., Tronzo, C., Andrews, M., Nelson, J., Sieracki, M., 1992. Relationship between cell volume and the carbon and nitrogen content of marine photosynthetic nanoplankton. Limnol. Oceanogr. 37, 1434-1446.

Viitasalo, M., Rautio, M., 1998. Zooplanktivory by Praunus flexuosus (Crustacea: Mysidacea): functional responses and prey selection in relation to prey escape responses. Mar. Ecol. Prog. Ser. 174, 77-87.

Webber, M., Edwards Myers, E., Campbell, C., Webber, D., 2005. Phytoplankton and zooplankton as indicators of water quality in Discovery Bay, Jamaica. Hydrobiologia 545, 177-193.

Yentsch, C.S., Menzel, D.W., 1963. A method for the determination of phytoplankton chlorophyll and phaeophytin by fluorescence. Deep Sea Res. 10, 221-231. 